\title{
NEW MEASURES OF THE COSTS OF UNEMPLOYMENT: EVIDENCE FROM THE SUBJECTIVE WELL-BEING OF 3.3 MILLION AMERICANS
}

\author{
John F. Helliwell \\ Haifang Huang \\ Working Paper 16829 \\ http://www.nber.org/papers/w16829 \\ NATIONAL BUREAU OF ECONOMIC RESEARCH \\ 1050 Massachusetts Avenue \\ Cambridge, MA 02138 \\ February 2011
}

Previously circulated as "New Measures of the Costs of Unemployment: Evidence from the Subjective Well-Being of 2.3 Million Americans." The research underlying this paper is part of the "Social Interactions, Identity and Well-Being' program of the Canadian Institute for Advanced Research, and we gratefully acknowledge the intellectual and financial support thereby available to us. We also grateful to the Gallup Organization for access to data from the Gallup/Healthways daily poll, and for helpful suggestions from George Akerlof, Andrew Oswald and Rainer Winkelmann. The views expressed herein are those of the authors and do not necessarily reflect the views of the National Bureau of Economic Research.

NBER working papers are circulated for discussion and comment purposes. They have not been peerreviewed or been subject to the review by the NBER Board of Directors that accompanies official NBER publications.

(C) 2011 by John F. Helliwell and Haifang Huang. All rights reserved. Short sections of text, not to exceed two paragraphs, may be quoted without explicit permission provided that full credit, including (C) notice, is given to the source. 
New measures of the costs of unemployment: Evidence from the subjective well-being of 3.3 million Americans John F. Helliwell and Haifang Huang

NBER Working Paper No. 16829

February 2011, Revised February 2014

JEL No. E24,H23,J64,J68

\begin{abstract}
Using two large US surveys, we estimate the effects of unemployment on the subjective well-being of the unemployed and the rest of the population. For the unemployed, the non-pecuniary costs of unemployment are several times as large as those due to lower incomes, while the indirect effect at the population level is fifteen times as large. For those who are still employed, a one percentage point increase in local unemployment has an impact on well-being roughly equivalent to a four percent decline in household income. We also find evidence indicating that job security is an important channel for the indirect effects of unemployment.
\end{abstract}

John F. Helliwell

Vancouver School of Economics

University of British Columbia

997-1873 East Mall

Vancouver BC V6T 1 Z1

CANADA

and NBER

john.helliwell@ubc.ca

Haifang Huang

Department of Economics

University of Alberta

8-14 HM Tory

Edmonton Alberta T6G 2H4 CANADA

haifang.huang@ualberta.ca

An online appendix is available at:

http://www.nber.org/data-appendix/w16829 
A growing literature uses data on subjective well-being to study macroeconomic determinants of life quality and relate them to policy discussions. Di Tella et al. (2001) use self-reported life satisfaction from the Euro-barometer surveys to estimate the unemployment-inflation tradeoff. Wolfers (2003) uses the same source of data to evaluate the cost of business cycle volatility. Di Tella et al. (2003) focuses on European style welfare state policies. There is also an active literature on the social-norm effects of unemployment (Clark, 2003; Clark et al., 2010; Powdthavee, 2007; Shields and Price, 2005; Shields et al., 2009; Chadi, 2013).

In this paper, we focus on the indirect or spillover effects of unemployment on the subjective well-being of U.S. residents, especially those who are still employed. Using two recent large surveys, we estimate the well-being costs of unemployment separately for different segments of the population, and decompose the total cost into monetary and nonmonetary costs of job losses, and the population-wide indirect effects. The indirect effects in the aggregate are found to be much larger than the direct effects. This suggests that more precise estimation and understanding of unemployment's indirect effects are essential for any cost-benefit analysis of policies designed to mitigate the economic and social effects of unemployment.

The two recent surveys we use are the Gallup-Healthways Well-Being Index from 2008 to 2011 and the Centers for Disease Control and Prevention's Behavioral Risk Factor Surveillance System (BRFSS) from 2005, or in cases from the early 1990s, to 2010. Both are large daily surveys, giving us a combined sample of more than 3 million U.S. respondents since 2005. The surveys include measures of subjective well-being that cover both life evaluations and emotional reports. The surveys' fine-grained geographic identifiers allow us to relate vari- 
ations in well-being to local labor market conditions. These two surveys will add question variety and much sample size and richness to a literature in which US studies were based mostly on the happiness question in the General Social Survey (GSS).

In addition to bringing in new survey data and finer-grain unemployment statistics, we experiment with a variety of identification strategies in order to provide more conclusive evidence and a better understanding on the spillover effects of unemployment. In the literature, Di Tella et al. (2001) and Wolfers (2003) find significantly population-wide negative effects using European and US survey data. Clark (2003) and Mavridis (2010), focusing on the labour force, uncover no statistically significant effects from the British Household Panel Study surveys. In this paper we will examine both the sample of employed workers and the wider population. More importantly, our analysis adopts a wide range of model specifications to make use of different sources of variations including those in official unemployment statistics, external industrial trends, unemployment by occupation and workplace downsizing. These experiments not only help check robustness, but also shed light on the structure and dynamics of the spillover effects of unemployment. In particular, we find evidence that the anticipation of future increases in local unemployment has a negative impact on the population's well-being, and that job security is an important channel underneath the indirect effects.

The structure of the paper is as follows. Section 1 reviews the literature. Section 2 describes the data and the estimation method. Section 3 presents empirical findings. Section 4 concludes. 


\section{Literature review}

The literature on the macroeconomics of well-being can be traced back to the seminal paper by Easterlin (1974) showing that the rise of income in the US since 1946 was not accompanied by an increase in its population's happiness. A more recent body of literature starts with Di Tella et al. (2001), which compares the costs of unemployment and inflation on happiness, using data from the Euro-Barometer surveys. It is found that both unemployment and inflation reduce satisfaction but the coefficient on the unemployment rate is almost twice as large as the coefficient on the rate of inflation. Blanchflower (2007) also reports that the negative effect of unemployment is greater than that of inflation. Di Tella et al. (2003) expand the study to cover more macroeconomic factors, and report that both the level of and the changes in GDP have positive effects on life satisfaction. Also using the Euro-Barometer as the main data source, Wolfers (2003) extends the literature to include measures of economic volatility as explanatory variables, and finds that greater unemployment volatility lowers well-being.

There is an active literature on the social-norm effect of unemployment, whereby unemployed individuals may suffer less in areas where more people are unemployed. Clark (2003) finds from British survey data that that aggregate unemployment has a greater negative effect on employed workers than it does on unemployed workers, consistent with the social-norm hypothesis. Clark et al. (2010) present consistent findings using the German Socio-Economic Panel, but also present evidence that the appropriate distinction may be between higher and lower levels of labour-market security, instead of between employment and unemployment. Powdthavee (2007) reports findings consistent with the socialnorm effects using South African survey data. Shields and Price (2005) use 
data from the Health Survey for England and report that individuals who live in areas with high degrees of deprivation report lower levels of psychological well-being, with an inverse u-shape relationship. They also find evidence consistent with the social-norm hypothesis. Shields et al. (2009) find from Australian survey data a negative relationship between neighborhood deprivation and individual life satisfaction, though the unemployment rate does not standard out by itself. Chadi (2013) uses the German Socio-Economic Panel Study to study the interaction between individual and aggregate unemployment, and draws a conclusion that is very different from the literature, that being unemployed is more distressing in regions with higher unemployment rates.

The literature using US data is more limited. Di Tella et al. (2001), Di Tella et al. (2003) and Wolfers (2003) use US data from the General Social Survey (GSS) in addition to European data. The GSS has interviewed, on average, 1,500 respondents a year since 1972, and has a three-step happiness question "Taken all together, how would you say things are these days - would you say that you are very happy, pretty happy, or not too happy?" Di Tella et al. (2001) find that the average happiness in the US is negatively correlated with yearto-year changes in inflation and in unemployment. Wolfers (2003) reports that state-level unemployment rate has a significantly negative effect.

Finally, we note a few examples that focus on the negative effects of individual unemployment. They are Winkelmann and Winkelmann (1998) and Kassenboehmer and Haisken-DeNew (2009). Our focus in this paper is the indirect effects of unemployment. 


\section{Data and the estimation method}

\subsection{Measures of well-being}

Our first data source is the CDC's Behavioral Risk Factor Surveillance System (BRFSS). The BRFSS is a state-based system of surveys collecting information on health risk behaviors, preventive health practices, and health care access. It collects information from more than 350,000 American adults (age 18 and over) a year in recent years. Starting from 2005, the BRFSS includes a question on life satisfaction: "In general, how satisfied are you with your life?" Respondents choose one of the following answers: very satisfied, satisfied, dissatisfied, or very dissatisfied. Oswald and $\mathrm{Wu}(2010)$ is a recent study that uses this measure of subjective well-being. As of April 2012, the latest available year is 2010.

As highlighted in Kahneman and Deaton (2010), there are interesting differences between life evaluations (such as the life satisfaction described above) and reports of emotional experiences. To ensure that our study covers both aspects of well-being, we include an alternative measure from the BRFSS based on a questions of mental health: "Now thinking about your mental health, which includes stress, depression, and problems with emotions, for how many days during the past 30 days was your mental health not good?" This question entered the BRFSS in 1993. We start the sample from 1994 in order to have a consistent set of income categories. About 4 million US residents answered the question of mental health from 1994 to 2010.

Measured by the two indicators described above, the US population is by and large happy. Overwhelmingly (93 percent), US residents are satisfied or very satisfied with their lives; slightly more choose "satisfied" as opposed to the top category (49 percent to 45). Among the rest, 4.5 percent say they 
are dissatisfied, only 1 percent choose "very dissatisfied." For the measure of mental health, most Americans (68 percent) say they never have any days in the past 30 when mental health was not good.

The second survey that we use is the Gallup-Healthways Well-Being Index, a daily survey of U.S. residents that interviews about 1,000 adults every day since 2008. One of its primary measures of subjective well-being is the Cantril Self-Anchoring Ladder (life ladder or ladder hereafter). It is the response to the following question: "Please imagine a ladder with steps numbered from zero at the bottom to ten at the top. Suppose we say that the top of the ladder represents the best possible life for you, and the bottom of the ladder represents the worst possible life for you. On which step of the ladder would you say you personally feel you stand at this time, assuming that the higher the step the better you feel about your life, and the lower the step the worse you feel about it? Which step comes closest to the way you feel?" The response thus has 11 levels from 0 to 10 in an ascending order, with higher values indicating better outcomes. From 2008 to 2011 (the latest available data as of April 2012), the Gallup-Healthways surveys provide a total of 1.4 million observations. 76 percent of them choose 6 or above (the middle rung is 5 ). The mode is 8 with a mass of 26 percent; 9 and 10 each accounts for about 9 percent. Among the rest, 14 percent choose 5,10 percent choose between 0 and 4 .

For measures of emotional well-being, we use a set of questions in the GallupHealthways survey that ask about survey respondents' experiences the day before the interview. Examples include "Did you smile or laugh a lot yesterday?" and "Did you experience the following feelings during a lot of the day yesterday? How about worry?" We identify eight questions, primarily based on availability, that are evenly divided into positive and negative emotions. The 
four positive emotions are "smile or laugh a lot", "enjoyment", "happiness", and "learn or do something interesting". The four negative ones are "worry", "sadness", "stress" and "anger". From the answers to these questions, we derive a score of positive emotions and a score of negative emotions. Specifically, we count the number of "yes" answers to the first four questions to reach a positive score. The resulting score has five steps from 0 to 4 . Between 2008 and 2011, 54 percent of the respondents report all four types of positive emotions and thus have the maximum score of four; 27 percent have a score of three; 14 percent have a score at two or one; only 4 percent report no positive experiences whatsoever. The negative score is constructed in the same manner based on the second set of emotions (worry, sadness, stress and anger). About 50 percent of the respondents report zero negative experience; 20 percent have a score of one; 14 percent two; 9 percent three; leaving less than 5 percent reporting the maximum score of four negative emotions.

In addition to the two scores for emotions, we use the same set of emotional reports to construct an indicator for the dominance of negative emotions. It serves as a proxy for the U-index that was introduced in Kahneman and Krueger (2006), who raise concern about measuring life satisfaction with numerical scales, because "there is no guarantee that respondents use the scales comparably" (p. 18). Instead they proposed a U-index ("U" is for "unpleasant" or "undesirable") to measure the proportion of time an individual spends in an unpleasant state. The Gallup-Healthways survey does not allow a literal construction of the index, because it does not record minutes or hours associated with each mood or experience. Instead we construct a proxy by comparing the score of negative experiences to the score of positive ones. If the negative score is strictly greater than the positive one, we classify the respondent's day 
(before the interview) as an "unpleasant" one in the dichotomous manner advocated in Kahneman and Krueger (2006) and assign the value 1 to the index; otherwise the index is zero. In the survey, 11 percent of respondents have a pseudo u-index that is 1 .

In total, our analysis makes use of six measures of subjective well-being in two distinct categories. The life assessment category includes the four-step life satisfaction and the 11-step life ladder. The emotional experiences category includes the self-reported number of days when mental health is not good and the pseudo $\mathrm{u}$-index that indicates the recent dominance of negative emotions over positive emotions. We also include the positive and negative components of the pseudo u-index as separate indices in the second category, as they may be differentially linked to unemployment and other factors influencing well-being

\section{$2.2 \quad$ Local and state-level statistics}

Unemployment statistics at the county level come from the Local Area Unemployment Statistics program of the Bureau of Labor Statistics (BLS). There were 3,141 counties or equivalents in the 2000 Census; most are included in our data (more than 3,100 counties in Gallup-Healthways and more than 2,300 in BRFSS). There are other statistics that serve specific purposes, such as statelevel unemployment rates, external industrial trends and unemployment rates by occupation. We will describe those data as they enter the analysis (Table A.1 in the appendix tabulates the sources).

\subsection{The relations among unemployment rates, income and subjective well-being}

This subsection presents simple data correlations before regression analysis in the next section. First we look at the cross-sectional relationship between av- 
Figure 1: Scatter plots of unemployment and happiness by states
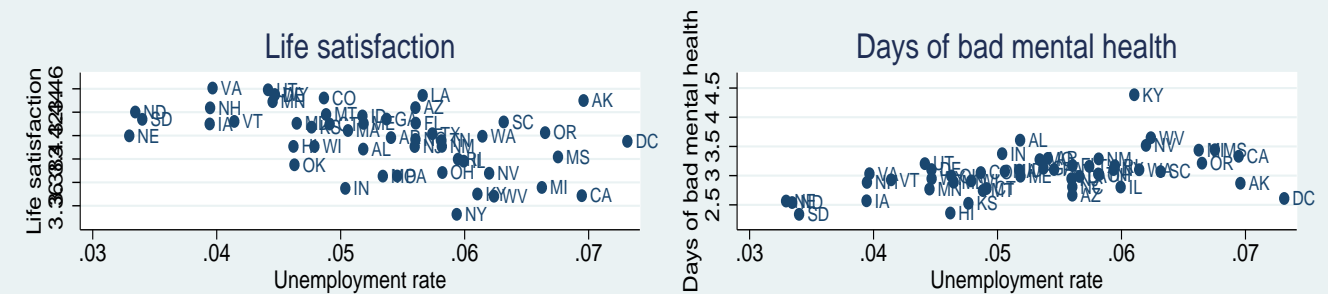

Source: BLS and BRFSS; 2005-2010 for life satisfaction; 1994-2010 for mental health
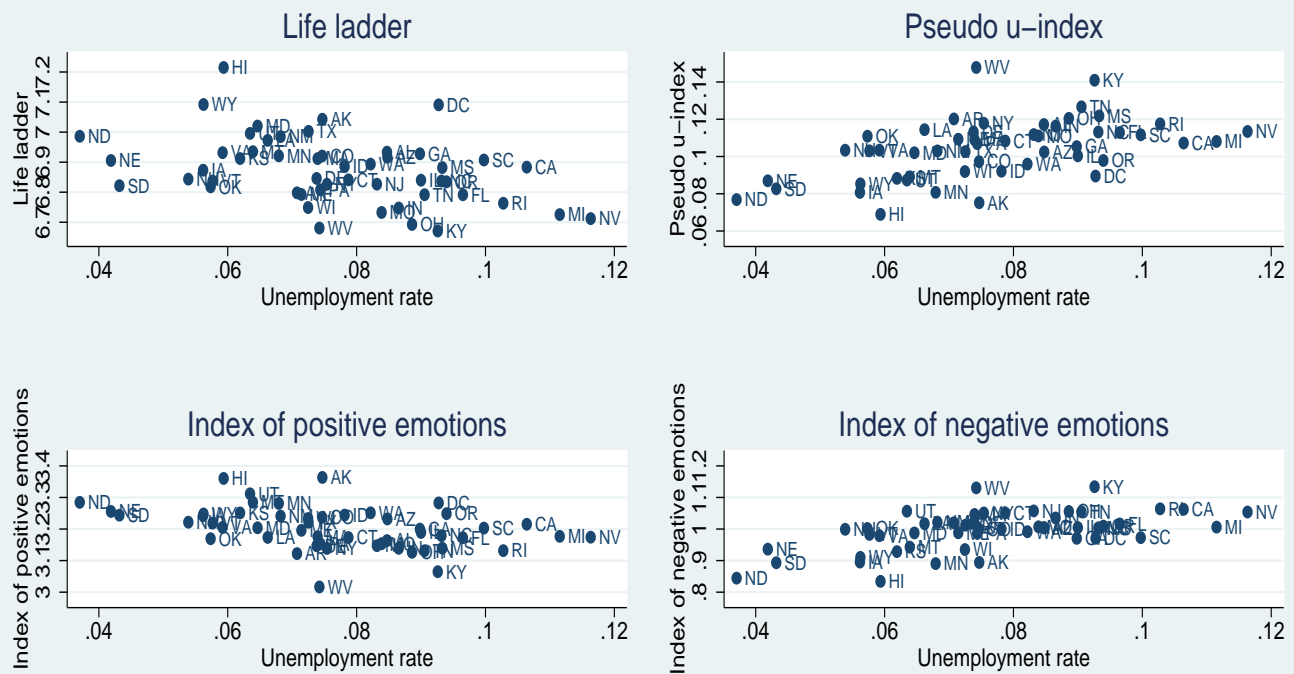

Source: BLS and Gallup-Healthways 2008-2011

erage happiness and unemployment rates. Figure 1 shows the scatter plots between the two variables across states over the sample periods. When deriving average happiness, we exclude unemployed workers from the sample. The purpose is to focus on the indirect effect of unemployment on people who are not themselves unemployed. The relationships are negative in all cases, all with conventional statistical significance. The correlations are thus consistent with the hypothesized indirect effects of unemployment. 
Figure 2: Trajectories of happiness by changes in unemployment rates
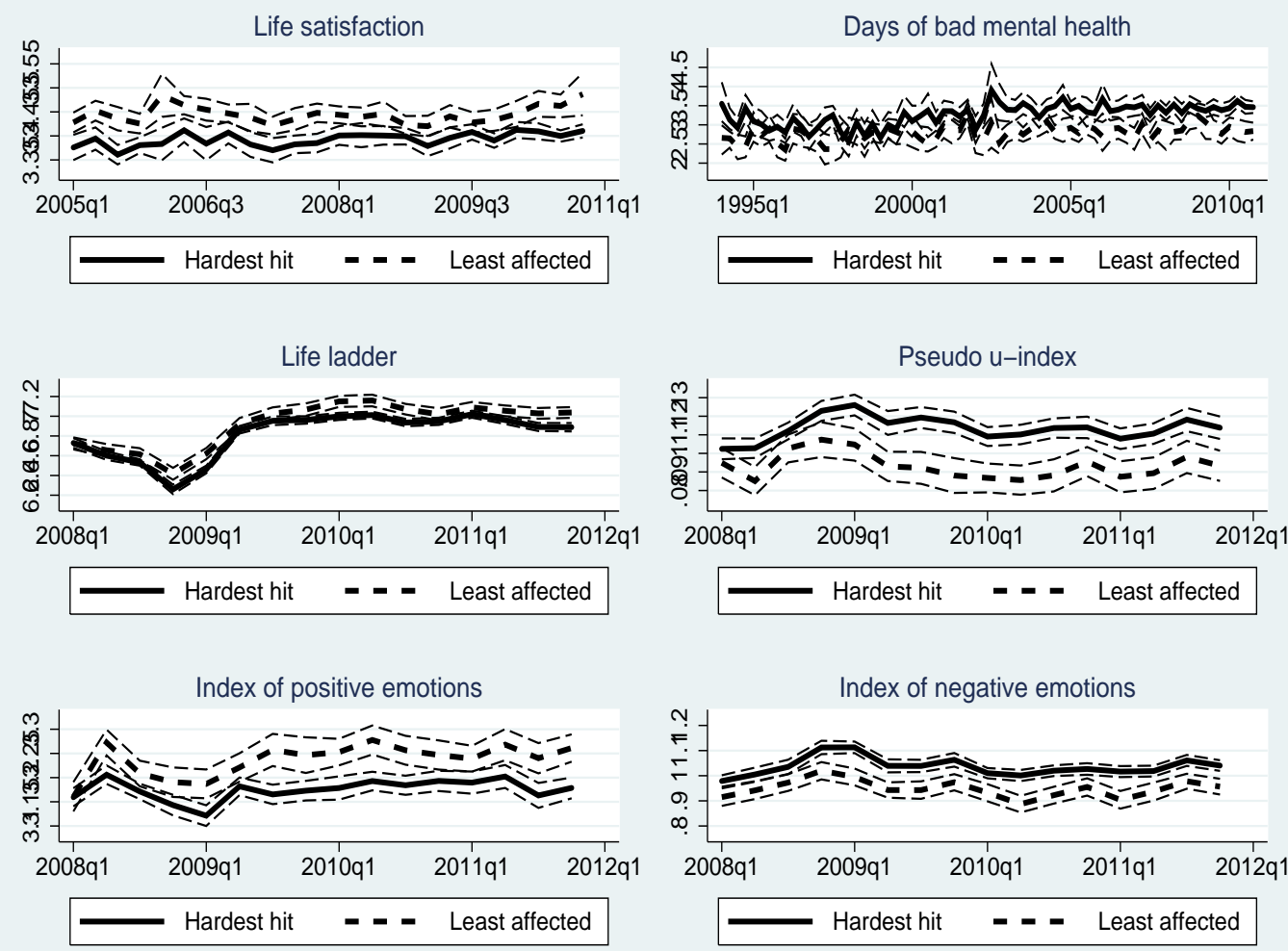

Thin dashed lines indicate 95\% confidence intervals

Next we look at variations over time by plotting the happiness trajectories according to local labor market conditions. Specifically, we divide counties into quartiles according to changes in the unemployment rate from 2007 to 2010. Those in the top quartile are the hardest hit, those in the bottom quartile the least affected. We then compare the two groups (top and bottom quartiles) in the trajectories of their happiness measures. Again, we exclude unemployed workers from the survey samples.

Figure 2 shows the plots. We note that the happiness measures are rather stable despite the severity of the recession. This is consistent with the findings 
reported in Deaton (2012). But national time-series do not reflect the substantial differences at the local level. Here our hypothesis is that counties that were the hardest hit during the recession experienced larger declines in well-being relative to the least affected group. We also note that the average levels of the survey responses are affected by changes in survey design. Specific to the Gallup-Healthways surveys, Deaton (2012) reported that "Life evaluation questions are extremely sensitive to question order effects-asking political questions first reduces reported life evaluation by an amount that dwarfs the effects of even the worst of the crisis." The large jump in life ladder after the change in questionnaire also shows up in Figure 2 in the middle panel on the left-hand side. In our regression analysis we will use time dummies to remove the impact of conditioning effects caused by change in questions order or in other aspects of the surveys.

Back to Figure 2 and the hypothesis that counties that were the hardest hit fared worse. The evidence is weak in BRFSS but stronger in the GallupHealthways surveys. In the BRFSS, the hardest-hit counties had lower life satisfaction even before the recession, starting from 2005 when the data became available. There is no obvious trend for the gap to narrow or widen thereafter. The BRFSS's other measure is the number of days with bad mental health. This measure begins from the early 1990s. Here the evidence is also mixed. In the 1990s the two groups are quite similar in this happiness measure. But the two began to diverge around 2003. Since then there is a statistically significant gap between the two groups in the expected direction; but the timing appears to be off.

There is stronger evidence in the Gallup-Healthways survey. For the Cantril ladder, the pseudo u-index and the index of positive emotions, there is little 
difference between the top and bottom groups in early 2008. A statistically significant gap, in the expected direction and consistent with the negative impact of unemployment, emerged in late 2008, at the onset of the financial crisis. The evidence is weaker for the index of negative emotions. According to this measure, the hardest-hit counties always fare worse than the better-off group even in early 2008. But the difference widens somewhat during the economic crisis, consistent with the hypothesized impact of unemployment.

To summarize the observations from the correlations reported above, both surveys, the BRFSS and the Gallup-Healthways, show strong cross-sectional correlations that are consistent with unemployment's negative impact on the happiness of people who are not themselves unemployed. The evidence is less clear cut in terms of dynamic relationships. Consistent observations are made in the Gallup-Healthways data, but not in the BRFSS. Our later regression analysis will try to control for relevant factors at the individual and local levels.

Next we examine the relationship between subjective well-being and income, which plays an important role in our analysis. We will express the estimated effect of unemployment in terms of income equivalents, i.e., the amount of monetary gains or losses that have the same effect on well-being as would a one-percent higher unemployment rate. ${ }^{1}$

Figure 3 plots the income-happiness relationship. The top panels are for life satisfaction and mental health from the BRFSS, both plotted against the logarithm of household income. Life satisfaction increases steadily and linearly with log income over the entire range. The measure of mental health also rises with

\footnotetext{
${ }^{1}$ Both BRFSS and Gallup-Healthways collect their income information as household income in categories. We turn the information into continuous values by estimating a monetary value for each category, assuming that the overall income distribution is lognormal. We do so for each individual year to allow the midpoint to grow over time. We then smooth the year-specific estimates using three-year moving averages centering on the current year, before turning them into constant 2010 dollars using the Consumer Price Index.
} 
Figure 3: Plotting the measures of well-being on household income
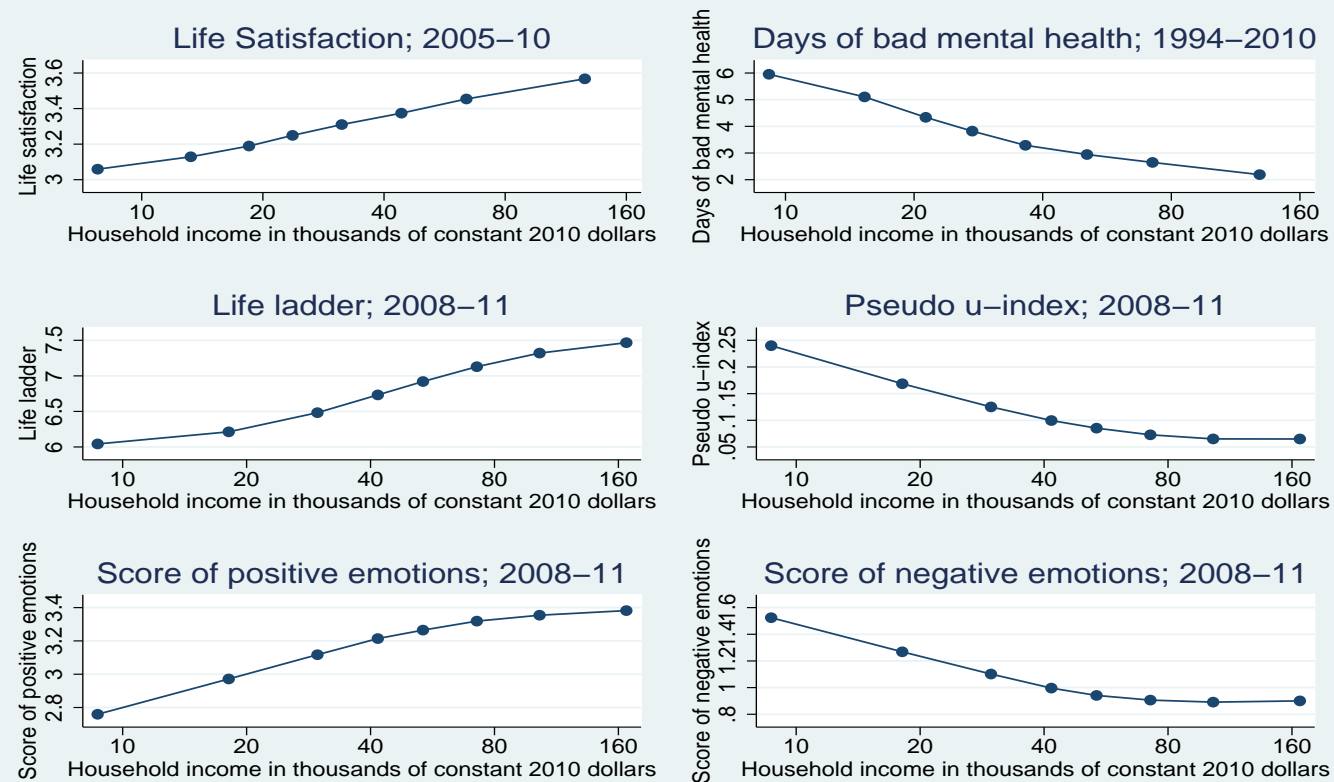

Source: Authors' calcuation based on the BRFSS and the Gallup-Healthways survey

log income, but the relation is stronger at lower levels of income and weakens as income rises. This distinction between life evaluative measures and emotional well-being is similar to those reported in Kahneman and Deaton (2010) based on the Gallup-Healthways surveys. They found that while the life ladder has a positive and relatively steady relation with log income, the relationship between emotional well-being and income flattens out after an annual household income of $\$ 75,000$. In the BRFSS, there does not appear to be a satiation point even for the measure of mental health. Figure 3 also plots the four measures of well-being in the Gallup survey against log income. They are similar to those in Kahneman and Deaton (2010): life ladder has a positive relation with log income throughout, while emotional well-being increases little, if at all, at higher levels of income.

We note that there is uncertainty on whether or not the cross-sectional cor- 
relations between income and SWB truly reflect income's effect on happiness. There are possibilities for both upward and downward biases. First, if SWB adapts to income changes over time, the effects of income would be stronger in the short run than in the long run. The cross-sectional correlations are more likely to pick up the weaker longer-term relationships, and thus to underestimate the short-run impact. In the opposite direction, there may be omitted factors in the regressions that are common to both higher income and better happiness outcomes. This will lead to over-estimation of the income effect. Despite the uncertainty, we use the income-equivalent representation for two reasons. First, the income-equivalents provide a standardized representation of estimated effects across multiple measures of well-being that have different scales ( 0 or 1,1 to 4 and 0 to 10$)$. Without a standardized scale, we would not be able to evaluate whether or not the estimated effects are comparable across the six measures of well-being. Secondly, the positive relationship between income and SWB is one of the most robust findings in the happiness research and is relatively well-known (Kahneman and Deaton, 2010). An income-equivalent presentation is thus a relatively easy-to-understand choice of standardization. In addition, we hope that the income equivalents can provide some indication, crude and imperfect as it may be, of the economic importance of unemployment's spillover effects.

Finally, we note that detailed summary statistics are in the appendix.

\subsection{Estimation method}

We employ a two-level regression approach for our analysis, using both individual and contextual information to predict individual well-being. The most important contextual variable is the county-level unemployment rate at the 
time of interview. The following equation describes the basic estimation, or Model-1.

$$
w_{(i, t), j}=\alpha_{0} \ln \left(y_{(i, t)}\right)+X_{(i, t)} \alpha_{1}+\beta_{0} u r_{j, t}+Z_{j, t} \beta_{1}+D_{t} \beta_{2}+u_{(i, t)}
$$

The dependent variable $w_{(i, t), j}$ is the well-being measure of worker $i$ in county $j$ who is interviewed at time $t$. In the subscript, we use a parenthesis to enclose $i$ and $t$ to highlight the fact that the surveys are not longitudinal. The time subscript $t$ is in the unit of quarters.

The first variable on the right-hand side is the logarithm of household income, or $\ln \left(y_{(i, t)}\right) .^{2}$ The vector $X_{(i, t)}$ has all other personal and demographic information including age categories, gender, marital status, educational attainment, race and labor force status. The variable $u r_{j, t}$ is the unemployment rate in county $j$ at time $t$. The vector $Z_{j, t}$ has other county-level information, including the log of average household income, the log of population density, the urbanization rate, the racial composition of each county's population, the percentage of owner-occupied housing (to measure the stability of population), and the longitude and latitude of the geographic centroid. It also includes

\footnotetext{
${ }^{2}$ We turn categorical income information into continuous values under the assumption that the income follows a log-normal distribution. We then assign the estimated mid-point value to each of the income categories. The midpoint estimate is likely to be less accurate for open-ended brackets, so we add to the regressions a dummy indicator for the top income category. We did not include a dummy indicator for the lowest income category, because the respondents in the bottom category are either few in number (in BRFSS) or removed before regressions (in Gallup-Healthways; more later on this). The top bracket presents a greater concern because it has a much larger concentration of survey respondents. The BRFSS's top bracket starts from $\$ 75,000$ in annual terms and includes about a quarter of the respondents in recent years. The Gallup-Healthways survey's top bracket starts from $\$ 120,000$ in annual terms and includes about 10 percent of the respondents. Following Kahneman and Deaton (2010), we deleted respondents in the Gallup-Healthways survey whose reported monthly incomes are lower than $\$ 500$, as such values are unlikely to be serious estimates of household income. The lowest BRFSS income bracket is $\$ 10,000$ a year or below; it includes about $4 \%$ of the sample in recent years. We keep those observations in our analysis. Both surveys have non-trivial portions of respondents with missing income information (about 10-20 percent). We include a dummy indicator for missing income in all regressions.
} 
dummy indicators for Alaska and Hawaii, so that the longitude and latitude variables reflect differences within the continental U.S. Finally, we include a set of year-quarter dummies $D_{t}$ to capture time trends as well as possible framing effects due to changes in the survey questionnaires.

We estimate Model-1 with ordered Probit for all measures of well-being except for the number of days when mental health is not good, which is estimated linearly. All estimations use weights from the surveys and allow errors to cluster at the county level.

Besides the basic model, we employ a set of alternative specifications for robustness and experiments. We run a horse race between state-level employment rates and county-level statistics, and find the latter to have closer correlations with subjective well-being. Other tests are listed below; we will provide more details as the analysis proceeds.

- Model-2 focuses on changes in unemployment rates instead of their levels.

- Model-3 uses fixed effects models to remove unobserved local characteristics.

- Model-4 uses instrumental variables (IV) to remove unobserved local characteristics.

- Model-5 adds regional dummies to remove inter-regional correlations between happiness and unemployment rates.

- Model-6 uses occupational-specific unemployment rates to explore job security as a channel responsible for unemployment's indirect effects.

We report estimates from the full-sample and, separately, the sample of employed workers. All regressions on the full sample control for respondents' 
own unemployment status so that the local unemployment rate picks up the indirect effect. The BRFSS provides an indicator of unemployed persons in all years. The Gallup-Healthways poll, however, changed its questions on labor market activity, starting from the second quarter of 2009, to match the unemployment definition in the Current Population Survey (CPS), creating a hurdle for identifying the unemployed in a consistent manner over time. We follow the CPS-based definition when the information is available. For the period before the second quarter of 2009, we define the unemployed as all those who are not working for pay, self-employed, full-time students, retired, home makers or disabled. This approach likely under-counts unemployment, because some of the people who are studying or working at home will be classified as being unemployed under the CPS definition if they are actively looking for work. Indeed, the national unemployment rate in 2008 that we calculated in the Gallup-Healthways is only $3.8 \%$, while it is $5.8 \%$ in the CPS. In contrast, the two sources generate almost-identical estimates of the unemployment rate in 2010 (9.7\% and 9.6\%, respectively). For our interest in unemployment's indirect effect, under-counting unemployment poses a challenge as it may inflate the estimated indirect effects. Fortunately, we can use our separate regressions that use only the sample of employed workers, thereby avoiding the need to identify unemployed individuals. The sub-sample regressions also highlight our interest on the indirect effects of unemployment.

\section{Empirical findings}

First the basic model, Table 1 presents estimates from the full sample and the sample of employed workers, in the top and bottom panels respectively. In all regressions, personal unemployment status is associated with lower well-being, 
Table 1: Estimates from the full samples (the top panel) and from the samples of employed workers (the lower panel showing only estimates of interest)

\begin{tabular}{|c|c|c|c|c|c|c|}
\hline & $\begin{array}{c}\text { Life } \\
\text { satisfaction }\end{array}$ & $\begin{array}{c}\text { Days of bad } \\
\text { mental health }\end{array}$ & $\begin{array}{c}\text { Life } \\
\text { ladder }\end{array}$ & $\begin{array}{l}\text { Pseudo } \\
\text { u-index }\end{array}$ & $\begin{array}{l}\text { Positive } \\
\text { emotions }\end{array}$ & $\begin{array}{l}\text { Negative } \\
\text { emotions }\end{array}$ \\
\hline \multicolumn{7}{|l|}{ Full Samples } \\
\hline Log of household income & $\begin{array}{c}0.2 \\
(0.008)^{* * *}\end{array}$ & $\begin{array}{c}-.90 \\
(0.03)^{* * *}\end{array}$ & $\begin{array}{c}0.24 \\
(0.004)^{* * *}\end{array}$ & $\begin{array}{c}-.27 \\
(0.004)^{* * *}\end{array}$ & $\begin{array}{c}0.17 \\
(0.003)^{* * *}\end{array}$ & $\begin{array}{c}.22 \\
(0.003)^{* * *}\end{array}$ \\
\hline LFS: Unemployed & $\begin{array}{c}-.40 \\
(0.009)^{* * *}\end{array}$ & $\begin{array}{c}2.38 \\
(0.06)^{* * *}\end{array}$ & $\begin{array}{c}-.34 \\
(0.007)^{* * *}\end{array}$ & $\begin{array}{c}0.3 \\
(0.009)^{* * * *}\end{array}$ & $\begin{array}{c}-.13 \\
(0.007)^{* * *}\end{array}$ & $\begin{array}{c}0.29 \\
(0.007)^{* * *}\end{array}$ \\
\hline Unemployment (fraction) in county & $\begin{array}{c}-.59 \\
(0.13)^{* * *}\end{array}$ & $\begin{array}{c}2.45 \\
(0.78)^{* * *}\end{array}$ & $\begin{array}{l}-1.01 \\
(0.1)^{* * *}\end{array}$ & $\begin{array}{c}0.91 \\
(0.11)^{* * *}\end{array}$ & $\begin{array}{c}-.61 \\
(0.08)^{* * *}\end{array}$ & $\begin{array}{c}0.61 \\
(0.08)^{* * *}\end{array}$ \\
\hline Male & $\begin{array}{c}-.05 \\
(0.004)^{* * *}\end{array}$ & $\begin{array}{c}-.96 \\
(0.02)^{* * *}\end{array}$ & $\begin{array}{c}-.17 \\
(0.002)^{* * *}\end{array}$ & $\begin{array}{c}-.06 \\
(0.004)^{* * *}\end{array}$ & $\begin{array}{c}-.07 \\
(0.003)^{* * *}\end{array}$ & $\begin{array}{c}-.12 \\
(0.003)^{* * *}\end{array}$ \\
\hline Age 18 to 29 & $\begin{array}{c}0.12 \\
(0.007)^{* * *}\end{array}$ & $\begin{array}{c}0.2 \\
(0.03)^{* * *}\end{array}$ & $\begin{array}{c}0.19 \\
(0.005)^{* * *}\end{array}$ & $\begin{array}{c}-.26 \\
(0.008)^{* * *}\end{array}$ & $\begin{array}{c}0.24 \\
(0.006)^{* * *}\end{array}$ & $\begin{array}{c}-.07 \\
(0.005)^{* * *}\end{array}$ \\
\hline Age 50 to 64 & $\begin{array}{c}0.06 \\
(0.005)^{* * *}\end{array}$ & $\begin{array}{l}-.72 \\
(0.03)^{* * *}\end{array}$ & $\begin{array}{c}0.02 \\
(0.003)^{* * *}\end{array}$ & $\begin{array}{c}-.04 \\
(0.005)^{* * *}\end{array}$ & $\begin{array}{c}0.01 \\
(0.004)^{* * *}\end{array}$ & $\begin{array}{c}-.15 \\
(0.004)^{* * *}\end{array}$ \\
\hline Age 65 or above & $\begin{array}{c}0.23 \\
(0.007)^{* * *}\end{array}$ & $\begin{array}{l}-2.19 \\
(0.04)^{* * *}\end{array}$ & $\begin{array}{c}0.35 \\
(0.004)^{* * *}\end{array}$ & $\begin{array}{c}-.57 \\
(0.009)^{* * *}\end{array}$ & $\begin{array}{c}0.21 \\
(0.005)^{* * *}\end{array}$ & $\begin{array}{c}-.68 \\
(0.006)^{* * *}\end{array}$ \\
\hline Edu: High sch. or below & $\begin{array}{c}-.04 \\
(0.006)^{* * *}\end{array}$ & $\begin{array}{l}0.02 \\
(0.02)\end{array}$ & $\begin{array}{c}-.01 \\
(0.004)^{* * *}\end{array}$ & $\begin{array}{c}0.08 \\
(0.005)^{* * *}\end{array}$ & $\begin{array}{c}-.15 \\
(0.004)^{* * *}\end{array}$ & $\begin{array}{c}-.02 \\
(0.004)^{* * *}\end{array}$ \\
\hline Edu: University degree & $\begin{array}{c}0.15 \\
(0.004)^{* * *}\end{array}$ & $\begin{array}{c}-.63 \\
(0.02)^{* * *}\end{array}$ & $\begin{array}{c}0.16 \\
(0.003)^{* * *}\end{array}$ & $\begin{array}{c}-.10 \\
(0.006)^{* * *}\end{array}$ & $\begin{array}{c}0.1 \\
(0.004)^{* * *}\end{array}$ & $\begin{array}{c}-.02 \\
(0.003)^{* * *}\end{array}$ \\
\hline Married/with partner & $\begin{array}{c}0.3 \\
(0.007)^{* * *}\end{array}$ & $\begin{array}{l}-.27 \\
(0.03)^{* * *}\end{array}$ & $\begin{array}{c}0.09 \\
(0.004)^{* * *}\end{array}$ & $\begin{array}{c}-.06 \\
(0.006)^{* * *}\end{array}$ & $\begin{array}{c}0.07 \\
(0.004)^{* * *}\end{array}$ & $\begin{array}{l}-.002 \\
(0.004)\end{array}$ \\
\hline Divorced/seprt./widowed & $\begin{array}{c}-.04 \\
(0.007)^{* * *}\end{array}$ & $\begin{array}{c}0.7 \\
(0.04)^{* * *}\end{array}$ & $\begin{array}{c}-.11 \\
(0.005)^{* * *}\end{array}$ & $\begin{array}{c}0.14 \\
(0.007)^{* * *}\end{array}$ & $\begin{array}{c}-.07 \\
(0.005)^{* * *}\end{array}$ & $\begin{array}{c}0.13 \\
(0.005)^{* * *}\end{array}$ \\
\hline Log(avg. income in cnty) & $\begin{array}{l}-.03 \\
(0.02)^{*}\end{array}$ & $\begin{array}{l}-.06 \\
(0.09)\end{array}$ & $\begin{array}{l}-.01 \\
(0.01)\end{array}$ & $\begin{array}{l}-.007 \\
(0.02)\end{array}$ & $\begin{array}{l}0.02 \\
(0.01)\end{array}$ & $\begin{array}{l}0.05 \\
(0.01)^{* * *}\end{array}$ \\
\hline Log(pop./sq. mile in cnty) & $\begin{array}{c}-.02 \\
(0.003)^{* * *}\end{array}$ & $\begin{array}{c}0.09 \\
(0.02)^{* * *}\end{array}$ & $\begin{array}{c}-.02 \\
(0.003)^{* * *}\end{array}$ & $\begin{array}{c}0.03 \\
(0.004)^{* * *}\end{array}$ & $\begin{array}{c}-.02 \\
(0.003)^{* * *}\end{array}$ & $\begin{array}{c}0.02 \\
(0.003)^{* * *}\end{array}$ \\
\hline $\begin{array}{l}\text { Other variables: see footnotes } \\
\text { Obs. } \\
R^{2}\end{array}$ & 1939405 & $\begin{array}{c}3310113 \\
0.08\end{array}$ & 1283025 & 1267079 & 1270822 & 1284254 \\
\hline$F$ statistic & 501.37 & 422.2 & 714.5 & 341.36 & 344.83 & 612.69 \\
\hline \multicolumn{7}{|l|}{ Samples of Employed Workers } \\
\hline Log of household income & $\begin{array}{c}0.22 \\
(0.01)^{* * *}\end{array}$ & $\begin{array}{c}-.74 \\
(0.04)^{* * *}\end{array}$ & $\begin{array}{c}0.25 \\
(0.005)^{* * *}\end{array}$ & $\begin{array}{c}-.20 \\
(0.006)^{* * *}\end{array}$ & $\begin{array}{c}0.1 \\
(0.004)^{* * *}\end{array}$ & $\begin{array}{c}-.16 \\
(0.004)^{* * *}\end{array}$ \\
\hline Unemployment (fraction) in county & $\begin{array}{l}-.60 \\
(0.19)^{* * *}\end{array}$ & $\begin{array}{l}2.57 \\
(0.9)^{* * *}\end{array}$ & $\begin{array}{l}-1.07 \\
(0.12)^{* * *}\end{array}$ & $\begin{array}{c}0.91 \\
(0.15)^{* * *}\end{array}$ & $\begin{array}{c}-.66 \\
(0.11)^{* * *}\end{array}$ & $\begin{array}{c}0.58 \\
(0.1)^{* * *}\end{array}$ \\
\hline $\begin{array}{l}\text { Other variables: see footnotes } \\
\text { Obs. } \\
R^{2}\end{array}$ & 863833 & $\begin{array}{c}1604097 \\
0.03\end{array}$ & 640286 & 634859 & 636078 & 640257 \\
\hline$F$ statistic & 295.4 & 204.1 & 414.18 & 113.01 & 117.06 & 217.1 \\
\hline
\end{tabular}

Notes: (1) Standard errors in parentheses. ${ }^{*}, * *$, and $* * *$ indicate statistical significance at 10 percent, 5 percent and 1 percent levels. (2) Other variables: Not all estimates are shown in the table. All regressions, including those in the lower panel on the samples of employed workers, have on their right-hand side a set of year-quarter dummies, a set of race/ethnicity dummies, the indicator of top income bracket, \&the indicator for missing income information, county-level average household income, population density, share of urban population, of owner-occupied housing, of black residents, of Hispanic residents, and of other minorities, the longitude and latitude of county centres, and indicators for Alaska and Hawaii. (3) The 2nd column uses survey linear regression; others use survey ordered probit. All use survey weights and cluster errors by county. 
while higher household income and higher levels of educational attainment are linked to higher well-being. Married couples are happier than the never-married singles, while the never-married are happier than the divorced, separated, or widowed. There is a robust U-shape in age, with happiness falling as age rises before picking up again in later years. Men report lower life satisfaction and life ladder than females, while women tend to report higher scores of emotional experiences in both the positive and negative directions.

We use county-level unemployment (as a fraction of the labor force) to capture the indirect effects of unemployment. The coefficients on county-level unemployment are consistently negative across all of our measures of subjective well-being. They are all statistically significant at the conventional levels $(1 \%$ or $5 \%$ ). Tables 2 expresses the estimated indirect effects as monetary equivalents that are constructed as ratios of coefficients, with estimates from the basic model presented in the column labeled as Model (1). In our estimations, unemployment is in fractional terms, while household income is in logarithms. The ratio of the unemployment coefficient to that on log income is thus the monetary equivalent, in logs, for a fractional unit change in the unemployment variable. In turn, this means that the ratio of coefficients is the percentage income equivalent for a one percentage point change in the unemployment rate.

The first column of Tables 2 shows the income equivalents from the basic model; they range from $2.7 \%$ to $4.2 \%$ in the full sample, and $2.7 \%$ to $6.3 \%$ in the sample of the employed. The point estimates from the employed sample tend to be are higher than those from the full sample in 5 of the 6 measures of well-being, indicating that labor market conditions may have weaker impacts on those outside the labor force, although in most cases the results are driven by a smaller estimated income effect among the working sample (i.e., a smaller 
Table 2: The estimated income equivalents, as percents, of unemployment's indirect effects, with standard errors in parentheses

\begin{tabular}{|c|c|c|c|c|c|c|c|}
\hline Measure of SWB & Population & Model-1 & Model-2 & Model-3 & Model-4 & Model-5 & Model-6 \\
\hline \multirow[t]{4}{*}{ Life satisfaction } & \multirow[t]{2}{*}{ All } & 3 & 1.2 & -1.7 & 4.6 & 1.6 & \\
\hline & & $(.6)^{* * *}$ & $(1.1)$ & $(1.2)$ & $(1.2)^{* * *}$ & $(.6)^{* *}$ & \\
\hline & \multirow[t]{2}{*}{ Employed } & 2.7 & 1.5 & -1.8 & 4.8 & 1.2 & \\
\hline & & $(.8)^{* * *}$ & $(1.4)$ & $(1.4)$ & $(1.7)^{* * *}$ & $(.75)^{*}$ & \\
\hline \multirow[t]{4}{*}{ Days of bad mental health } & \multirow[t]{2}{*}{ All } & 2.7 & 3.9 & -.4 & 4.6 & 2.5 & \\
\hline & & $(.9)^{* * *}$ & $(1.4)^{* * *}$ & (1) & $(2)^{* *}$ & $(1)^{*}$ & \\
\hline & \multirow[t]{2}{*}{ Employed } & 3.5 & 4.1 & .4 & 4.4 & 2.8 & \\
\hline & & $(1.3)^{* * *}$ & $(2.1)^{* *}$ & $(1.4)$ & $(2.8)$ & $(1.5)^{*}$ & \\
\hline \multirow[t]{4}{*}{ Life ladder } & \multirow[t]{2}{*}{ All } & 4.2 & 5.9 & 2.3 & 7.9 & 3.2 & \\
\hline & & $(.4)^{* * *}$ & $(.7)^{* * *}$ & $(.6)^{* * *}$ & $(.9)^{* * *}$ & $(.4)^{* * *}$ & \\
\hline & \multirow[t]{2}{*}{ Employed } & 4.4 & 5.9 & 2.4 & 8.2 & 3.2 & 4.8 \\
\hline & & $(.5)^{* * *}$ & $(.9)^{* * *}$ & $(.9)^{* *}$ & $(1)^{* * *}$ & $(.5)^{* * *}$ & $(.3)^{* * *}$ \\
\hline \multirow{4}{*}{ Pseudo u-index } & \multirow[t]{2}{*}{ All } & 3.4 & 4.4 & 1.1 & 3.4 & 2.3 & \\
\hline & & $(.4)^{* * *}$ & $(.8)^{* * *}$ & $(.8)$ & $(.9)^{* * *}$ & $(.4)^{* * *}$ & \\
\hline & \multirow[t]{2}{*}{ Employed } & 4.7 & 6.7 & 3.3 & 6.6 & 2.9 & 4.1 \\
\hline & & $(.8)^{* * *}$ & $(1.7)^{* * *}$ & $(1.6)^{* *}$ & $(1.6)^{* * *}$ & $(.7)^{* * *}$ & $(.6)^{* * *}$ \\
\hline \multirow[t]{4}{*}{ Positive emotions } & \multirow[t]{2}{*}{ All } & 3.7 & 3.5 & 1.6 & 2.2 & 2.9 & \\
\hline & & $(.5)^{* * *}$ & $(.9)^{* * *}$ & $(.9)^{*}$ & $(1.1)^{* *}$ & $(.4)^{* * *}$ & \\
\hline & \multirow[t]{2}{*}{ Employed } & 6.3 & 6.8 & 3.7 & 5.6 & 4.4 & 11.2 \\
\hline & & $(1)^{* * *}$ & $(1.9)^{* * *}$ & $(1.8)^{* *}$ & $(2.1)^{* * *}$ & $(.9)^{* * *}$ & $(.9)^{* * *}$ \\
\hline \multirow[t]{4}{*}{ Negative emotions } & \multirow[t]{2}{*}{ All } & 2.8 & 4.2 & .3 & 3 & 2 & \\
\hline & & $(.4)^{* * *}$ & $(.7)^{* * *}$ & $(.7)$ & $(.8)^{* * *}$ & $(.3)^{* * *}$ & \\
\hline & \multirow[t]{2}{*}{ Employed } & 3.6 & 5.9 & .8 & 4.8 & 2.3 & -1 \\
\hline & & $(.6)^{* * *}$ & $(1.3)^{* * *}$ & $(1.2)$ & $(1.3)^{* * *}$ & $(.6)^{* * *}$ & $(.4)^{* *}$ \\
\hline
\end{tabular}

$*, * *, * * *$ : significance at $10 \%, 5 \%$ and $1 \%$, respectively.

The table shows the estimated coefficients on the unemployment-rate variables of interest (in fractions) expressed in proportion to the estimated coefficients on logged household income. Standard errors are calculated using the Delta method.

Model-1: estimates from the basic specification with county-level unemployment rates.

Model-2: estimated effects of recent increases in county-level unemployment rates.

Model-3: estimates from the fixed effects model.

Model-4: estimates from the IV model.

Model-5: adding regional dummies to the regressions.

Model-6: estimates based on occupation-specific unemployment rates.

In models 1, 3, 4 and 5, the unemployment variable of interest is the level of local unemployment rates (actual or instrumented). In model 2, the unemployment variable is the change in local unemployment rate from same quarter last year. In model 6, the unemployment variable is the occupation-specific unemployment rate.

denominator in the calculation of the equivalent income). There are not obvious patterns of differences between the evaluative measures (life satisfaction and life ladder) and the four measures of emotional reports. Take the life ladder and 
the pseudo u-index as an example: the estimates are similar and within two standard errors of each other. The average from the first four measures (leaving out the two components of the u-index) is $3.3 \%$ for the full sample and $3.8 \%$ for the sample of employed workers.

Our first robustness test is to repeat the regressions but with unemployment rates at the state level added as an extra variable, in addition to the countylevel unemployment rate. This test serves two purposes. First, it presents a horse race between the two unemployment rates to see which one is more closely related to the measures of well-being. Secondly, it detects potential spillover effects from state-level unemployment beyond those at the local level. The results, presented in the appendix as the first panels of Tables A.7 and A.8, suggest that county-level unemployment tends to have a tighter statistical relationship with subjective well-being. In 9 out of the 12 regressions, the estimated coefficients on county-level unemployment are statistically significant, compared to 3 in the case of state-level unemployment. Importantly, however, we find that the state-level unemployment rates almost all have the same sign as the county-level unemployment rate. In most cases, other than the emotional reports in the Gallup-Healthways, they have roughly similar magnitude to those at the county level. Such findings are indicative of important spillover effects from statewide unemployment: it exerts a negative impact on well-being on a scale comparable to that of county-level unemployment.

The next model, labeled as Model-2 in Tables 2, intends to shed light on the dynamic aspects of unemployment's indirect effects. It does so by treating recent increases in unemployment rates separately from the levels. If the population has a tendency to adapt gradually to a higher level of unemployment, a recent increase in unemployment likely has a greater impact on well-being than 
the level per se. Specifically, we break time- $t$ unemployment rate into a base component $u r_{j, t-4}$ (where $t-4$ is the same quarter last year), and a change component, $\Delta u r_{j, t}=u r_{j, t}-u r_{j, t-4}$. The regressions then include both $\Delta u r_{j, t}$ and $u r_{j, t-4}$ on the right-hand side. Our interest is in the change component; the base serves as a control. Tables A.7 and A.8 present the estimated coefficients on both components, while the second column in Table 2 presents the income equivalents only for the change components $\Delta u r_{j, t}$. In all cases, recent increases in unemployment rates are negatively linked to well-being. The estimated effects are mostly statistically significant, except when life satisfaction in the BRFSS is the dependent variable, in which case it is the lagged unemployment rate that has strong statistical significance with the expected sign. In terms of magnitudes, the effects of recent changes tend to be greater than estimates based on the level of unemployment rates (the first column); but the confidence intervals overlap in all cases. The evidence for adaptation is thus indicative but not overwhelming.

The next two models both deal with possible concerns about unobserved local characteristics. The findings described above are based on variations in unemployment rates and happiness at the county level. A concern is that there are unobserved local characteristics responsible for both unemployment and (un)happiness. We deal with this concern using both fixed effects and instrumental-variables (IV) models. The fixed-effect model eliminates all crosscounty variations, including any unobserved ones. The IV approach uses variations that are clearly driven by labor market fluctuations.

The third column of Table 2, labeled as Model-3, has the income equivalents from the fixed effects models. Tables A.7 and A.8 show the underlying 
estimates. $^{3}$ The income equivalents from the fixed effects models are clearly weaker than those from the basic model. In the BRSS, none of the estimates is significant. In the Gallup-Healthways survey, only 4 of the 8 estimates are significant at conventional levels, with a fifth one having a $10 \%$ borderline significance. The size of the income equivalents are also smaller than those from previous models. Among the conventionally-significant estimates, they range from $2.3 \%$ to $3.7 \%$, just slightly over half of their counterparts from the basic model in column 1.

A fixed-effects model is not a costless way to handle unobserved factors. In a short time horizon, it has difficulty distinguishing stable local fixed effects from the well-being consequences of a persistent increase in unemployment that occurred before the sample period. Our samples indeed have short horizons: five of the six well-being measures have a sample period of either 4 or 6 years. Fixed-effects models are also vulnerable to what we call the anticipation effect, when future increases in unemployment are foreseen and such predictions reduce today's well-being (more discussion of this later).

An IV approach is another way to deal with the problem of omitted variables. We will instrument county-level unemployment rates with observable features in the labor market while leaving out the residuals including any unobserved components. Compared to the fixed-effects model, the IV approach

\footnotetext{
${ }^{3}$ We switch to linear models in order to take advantage of STATA's built-in command to handle large dummy-variable sets (about 3000 counties in our case). The choice is also motivated by the incidental parameters problem that renders fixed effects probit models inconsistent. The choice of linear vs probit models makes little qualitative difference in SWB regressions, as documented in Ferrer-i-Carbonell and Frijters (2004). But it does mean that the estimates in Tables A.7 and A.8 for the fixed effects models are not strictly comparable to those from the probit models. The income equivalents in Table 2, on the other hand, are comparable as they are expressed as income equivalents (or ratio of coefficients). Ratios of coefficients are robust to the choice of probit or linear models, because switching from one to the other tends to affect estimated coefficients proportionally (see Helliwell and Huang $(2009))$.
} 
allows us to keep using parts of the cross-county variation that are clearly driven by labor-market fluctuations. Specifically, we calculate the time series of likely employment losses for individual counties based on their shares of employment by industry and external state-wide employment losses by industry. We then use the contemporaneous and lagged likely losses to instrument for local unemployment rates in standard two-stage regressions. This approach leaves out unobserved local characteristics except for those that are correlated with local compositions of industries or with statewide loss of employment by industries, the only two pieces of information used in the IV approach. ${ }^{4}$

We implement the IV approach using the industry classification at the level of 11 supersectors defined in the BLS. ${ }^{5}$ The current likely loss and its three year lags, namely LikelyLossRate ${ }_{j, s, t-k}$ for $k=0,4,8,12$, are then used as instruments in a two-stage least squares IV regressions. These likely employment losses are strong predictors of county-level unemployment rates: even without any co-variates, the likely losses explain $42 \%$ of the variation in the county-level unemployment rates since 2005 .

\footnotetext{
${ }^{4}$ Formally, the likely rate of employment losses from the same quarter last year (i.e., from $t-4$ to $t$ ) in county $j$ of state $s$ is

$$
\text { LikelyLossRate }_{j, s, t}=-\frac{\sum_{x=1}^{X}\left(\frac{N_{x,-j, s, t}}{N_{x, s,-j, t-4}}-1\right) N_{x, j, s, t-4}}{\sum_{x=1}^{X} N_{x, j, s, t-4}}
$$

The loss rate is expressed as a fraction. The denominator on the right-hand side is the total employment in the county $j$ at $t-4$, expressed as the number of employed workers $N$ summed across industry $x$. The numerator is the likely employment losses, summed across industries. The likely losses are in turn the product of two factors: one is the proportional employment losses by state and industry (excluding the influence of county $j$ ); the other the number of workers by industry in county $j$ in the base period. We note that the subscription $-j$ in the numerator means that we exclude county $j$ when calculating the state-wide industrial trend in $\left(\frac{N_{x,-j, s, t}}{N_{x, s,-j, t-4}}-1\right)$ to ensure that the state-wide industrial trend is strictly external to county $j$ itself.

${ }^{5}$ They are construction, education and health services, financial activities, information, leisure and hospitality, manufacturing, natural resources and mining, other services, professional and business services, trade, transportation, and utilities, and the unclassified.
} 
We label the IV model as Model-4 in Table 2 for the income equivalents. Tables A.7 and A.8 have the underlying estimates, where 11 of the 12 indirect effects are significant at conventional levels. As income equivalents, they tend to be greater than those from the basic model, particularly so in the sample of employed workers. For example, local unemployment's impact on life satisfaction in the basic specification is $2.7 \%$ in the working samples. The corresponding IV estimate is $4.8 \%$. In the case of life ladder, the estimated effect jumps from $4.4 \%$ to $8.2 \%$ with no overlap in the confidence intervals. The contrast is even greater between the IV estimates and the fixed-effects estimates in column Model-3. ${ }^{6}$

Why are the IV estimates greater than those estimates based on the actual unemployment rates? Two likely explanations are adaptation and anticipation. By adaptation, we mean that recent employment losses have greater impacts on well-being than the level, because people are able to adjust to higher unemployment; those who cannot adjust may choose to migrate. For those who remain on their jobs, the adaptation may in part reflect a lower threat of job losses compared to the period when unemployment is rising. Psychologists regard threat as a cause of "a drawn-out process of appraisal and reappraisal" leading to the feelings of helplessness and confusion (Lazarus and Folkman,

\footnotetext{
${ }^{6}$ There is a difference in sample period between the IV model and other models; but that sample period is not responsible for the observed pattern of difference in estimates. The IV model (column Molde-4) does not include 2011 data, because as of April, 2012, the necessary QCEW full-year data are not yet available. This is not a concern for the BRFSS data, since its sample period ends with 2010. For the Galllup-Healthways data, Model-1 and Model-3 are based on the 2008-2011 sample; the IV model uses the 2008-2010 sample. We can remove the difference in sample periods by running Model-1 and Model-3 using only the 2008-2010 data. From such regressions, the estimated income equivalents among employed workers is $4.3 \%$ in the case of life ladder, $4.5 \%$ for the u-index, $5.8 \%$ for the positive emotions and $3.4 \%$ for negative emotions. In the fixed-effects model, they are $1.6 \%, 2.2 \%, 3.8 \%$ and $0.07 \%$, respectively. Without exception, they are either smaller or similar to those from the 4-year estimates. As a result, they are all substantially smaller than the IV estimates, the pattern of difference that we focus on.
} 
1984, p. 92). A stabilization of unemployment, even if it is to a still-high level, can be beneficial for those who are still employed. This is a hypothesis that is supported in a previous robustness test, shown in Model-2, that indicating the negative SWB effects of recent rises in unemployment tend to be greater than those estimated based on contemporaneous levels of unemployment. Anticipation is about the threat of job losses in the immediate future. One of our later analyses shows that working in a company that is downsizing is more damaging to the emotional measures of SWB than is actually being unemployed. This is also consistent with psychologists' emphasis in the anticipatory aspect of threat (see chapter 2 of Lazarus, 1966, for discussions and evidence). The instruments we use are predicted employment losses based on local industry shares and the wider area's employment trends. They very likely can predict a county's employment trends in the near future better than the current unemployment rate. Indeed, in a panel of county-level unemployment rates, our instruments (namely LikelyLossRate L $_{j, t-k}$ for $k=0,4,8,12$ ) predict the unemployment rises over the next year (namely, $u r_{j, s, t+4}-u r_{j, s, t}$ ) with an r-squared of $23 \%$ in the $1990-2010$ period (48\% in the $2005-2010$ period). The current employment rate's predictive power is much poorer with an r-squared that is $3 \%$ and $6 \%$ in those two periods, respectively. If the anticipation of future employment losses has a negative effect on well-being, we should expect the IV estimates to be greater than those from the basic model.

The anticipation effect can also explain why the estimates from the fixedeffects models are weak: if the anticipation effect is substantial, the fixed-effects estimates are misleading. Consider a sample with a short time horizon (a small number of years). Let's say a county's unemployment rate rises substantially from the early years to the later years. The fixed-effect estimations will take 
an average of the two periods' unemployment rates and treat it as the county's long-term unemployment level. The earlier period is the "good" time because its unemployment rate is low; the latter period the "bad" time. But the anticipation effect concentrates more in the earlier period, when the residents can see that the bad times are coming based on industrial trends. The fear is in fact stronger in the "good" time. The anticipation effect thus weakens the relationship between current employment rates and well-being in the fixed-effect models. The larger is the anticipation effect, the weaker are the estimates from the fixed-effect models. Finally, we note that a strong anticipation effect is consistent with job security being an important channel behind the indirect effect of unemployment. When workers expect possible job losses in the future, the weakened sense of job security lowers well-being. After the employment losses actually take place, however, the still-employed workers may sense an improvement in their job security and thus experience a recovery in well-being. Later we will present analysis that focuses on the job security channel.

There is one more potential explanation for why county fixed-effect models return lower estimates: regional differences in happiness that are correlated with unemployment. County-level dummies variables remove local effects and thus regional differences as well. What are the likely causes of regional differences? Some of those may have to do with differences in population density, urban shares, and race/ethnic composition. Our basic model already has those control variables, in addition to average income, longitude, latitude and others. The model can thus handle systemic regional differences due to the observed factors. Problems arise, however, from unobserved or omitted factors. We can address this concern by adding regional dummy variables to the model, which will remove unemployment-happiness correlations between regions. Specifically, 
we use the Census Bureau's definition of regions: Northeast, Midwest, South and West. There are substantial differences in unemployment rates among regions. In 2009, for example, the population-weighted unemployment rate was 8.4 percent in the Northeast, 9.7 percent in the Midwest, 8.9 percent in the south and 10.1 percent in the West.

We report the test results in Model (5) of Tables 2. The appendix Tables A.7 and A.8 show the underlying estimates. Adding regional dummies does indeed lower the estimates for unemployment's indirect effect, indicating that the inter-region correlations between unemployment and happiness are steeper than those within regions. Almost all estimated income equivalents retain strong statistical significance, with only a few in the BRFSS dropping to the borderline significance of 10 percent confidence level. Quantitatively, the estimated income equivalents fall by an average of a quarter in the full sample, and a third in the sample of employed workers. The estimates now range from 1.2 percent to 4.4 percent with an average of 2.4 percent in the full sample and 2.8 percent in the sample of employed workers.

A more drastic way to control for regional differences would be to add state dummy indicators, thereby eliminating all inter-state correlations in well-being and unemployment. We decide against this approach for two reasons. First, inter-state variations account for a large proportion of the differences in unemployment rates. In 2009, 56 percent of the variation in the county-level unemployment rates is among states. Second, excluding inter-state differences ignores the potential spillover effects from statewide unemployment on happiness. One of our earlier tests provides indicative evidence of the statewide spillover effect. It uses regressions that include both county-level unemployment rate and state-level unemployment rate on the right-hand side as pre- 
dictors. The state-level unemployment rate has an additional contribution to the dependent variables on top of those from county unemployment. In most cases, the state-level effects are comparable in magnitude to the county-level effects. Removing the state-level spillover effect thus is thus likely to weaken the link between unemployment and happiness. However, we should note that even with the state-level dummies, we still find statistically significant estimates in the Gallup-Healthways that ranges from 1.5 to 4.6 percent in terms of income equivalent, with an average of 1.9 percent in the full sample and 3 percent in the sample of employed workers. In the BRFSS, however, all estimates lose statistical significance and are quantitatively small (see appendix Tables A.9 and A.10). We note that there are more counties in the GallupHealthways surveys than in the BRFSS (3100 counties versus 2300) and thus more variation across counties within states. Another possible explanation is that happiness-unemployment correlations over time are lower in the BRFSS than in the Gallup-Healthways, as shown by Figure 2.

\section{The job-security channel behind the indirect effect}

Why does local unemployment, or the anticipation of its increase, reduce subjective well-being? One likely channel is job security: rises in local unemployment lead to fear of losing one's own job. ${ }^{7}$ But there are other possibilities. Higher unemployment may lead to deterioration of social conditions such as more crime. $^{8}$ Rapid reshuffling in the labor-market can be disruptive in the

\footnotetext{
${ }^{7}$ A recent paper, Luechinger et al. (2010), tries to disentangle the effects by comparing the well-being of public-sector workers, who have greater job security, to that of private-sector workers. They find that the former are less affected by high levels of unemployment. Such findings are certainly consistent with the job-security channel. See also Clark et al. (2010).

${ }^{8}$ The evidence linking crime to unemployment is mixed. At least one study, Raphael and Winter-Ember (2001), using defense contracts and state-specific exposure to oil shocks to instrument for unemployment rates, found significantly positive effects of unemployment on property crime. On the other hand, US crime rates continued their downward trend during
} 
short run. While it is not easy to disentangle the mixture, our reasoning above suggests an important role for the job-security channel. In this section, we present further relevant observations regarding the job-security channel.

We recognize that the estimated effect of local unemployment is a mixture of the effects of lower job security (fear of job losses due to a bad local economy) and of other local channels (say social disruption). The local unemployment rate alone cannot tell them apart. We need variations that are related to job security but are not local in nature. The unemployment rate by occupation meets these criteria. It is linked to job security. It may have some correlations with local unemployment due to industrial clustering. In a manufacturing recession, for example, residents in manufacturing regions face higher local unemployment rates and on average higher levels of occupation-specific unemployment rates. But we can deal with these correlations by controlling for local labor market conditions. If the orthogonal part of the occupational rate affects well-being, we attribute that particular impact to job security instead of local factors.

Below we conduct the exercise using the Gallup-Healthways survey, which classifies workers into 11 occupation categories. ${ }^{9}$ The quarterly time series of occupation-specific unemployment rates are from the Current Population Surveys (CPS). We cannot do the same for the BRFSS, which does not identify the Great Recession. The 2010 FBI Uniformed Crime Report indicates that property crimes in the US fell from 9.8 million in 2008 to just above 9 million in 2010. Even though national figures cannot reveal local heterogeneities, it does raise questions about the importance of business cycles in crime trends.

${ }^{9}$ The following is the list: 1 . Professional worker - lawyer, doctor, scientist, engineer, nurse, accountant, computer programmer, architect, investment banker, stock brokerage, marketing, musician, artist; 2. Manager, executive, or official - in a business, government agency, or other organization; 3. Business owner; 4. Clerical or office worker in business, government agency, or other type of organization; 5. Sales worker 6. Service worker- policeman/woman, fireman, waiter or waitress, maid, nurse's aide, attendant, etc; 7. Manufacturing or production worker; 8. Construction or mining worker; 9. Transportation worker; 10. Installation or repair worker; 11. Farming, fishing, or forestry worker. 
occupations. We run the regressions only on the sample of employed workers, as unemployment by occupation is less relevant for people outside the labor force.

The last column in Table 2 presents the income equivalents for the occupational unemployment rate. The appendix tables A.8 shows the underlying estimates. In all regressions, local unemployment has negative and significant effects on employed workers' well-being. The occupational rate has similar effects on the life ladder and the pseudo u-index, as well as the positive component of the u-index. For the negative emotions, however, a higher occupational rate leads to a reduction instead of an increase. But this beneficial impact is small and is completely overwhelmed by the reductions in positive emotions. As a result, a higher occupational unemployment rate significantly increases the pseudo u-index, or the chance that the positive emotions become dominated. In term of income equivalents in Table 2, the occupation-based estimates are broadly comparable to county-based estimates. For the life ladder, the comparison is $4.8 \%$ for the occupational rate and $4.4 \%$ for the county rate in column 1. For the pseudo u-index, it is $4.1 \%$ to $4.7 \%$. In both cases, the confidence intervals overlap.

There is broad similarity between the occupation-based estimates and the county-based estimates. The job security channel is present in both estimates. If our assumption is right, that the occupational rates affect well-being only through the job security channel, the quantitative similarity would then suggest that job security is the major driver behind local unemployment rate's indirect effect on well-being.

Our final test attempts to provide direct evidence on the well-being impact of job security. It uses a Gallup-Healthways survey question: "Based on what 
you know or have seen, would you say that, in general, your company or employer is hiring new people and expanding the size, not changing the size of its workforce, and letting people go and reducing the size." In regressions that are otherwise identical to model (1), we find that workforce downsizing, relative to "not changing the size of its workforce", has substantial negative effect on employed workers' well-being. Workforce expansion, on the other hand, is associated with greater happiness. Appendix Table A.11 reports the estimates. The coefficients on the dummy indicators of downsizing and expanding are statistically significant in all cases. In terms of magnitude, the negative effects of downsizing are close to or exceed the impact from lowering the log of income by an entire unit. These extremely large estimated impacts are probably due to the immediacy of the danger of job losses. For the three measures of emotional reports, the impact of downsizing is greater than that of actual unemployment (in terms of income equivalents compared to their counterparts found in the baseline regressions). The fear of job losses thus seems to be more detrimental than the actual status of unemployment. This is not true for life evaluations, for which the actual unemployment status hurts more than does downsizing.

Overall, the two tests above demonstrate that job security is an important channel for the spillover effect of unemployment. This is also consistent with the emphasis and finding in Clark et al. (2010), which find that regional unemployment has stronger negative effects for men with higher levels of labour-market security, and weaker ones for those who already fare poorly in the labour market. 


\section{Accounting for the well-being impacts of unemployment}

The analysis above focuses on indirect effects, but unemployment also has direct effects on the unemployed. This section decomposes unemployment's influence on the subjective well-being of a population into three parts. The direct monetary cost is the loss of well-being due to income losses from unemployment. The direct nonpecuniary cost is the further loss of well-being suffered by those who become unemployed. The indirect cost is the loss suffered by those who are not themselves unemployed. We conduct the exercise using estimates from the basic specification (Model-1), which generates estimates that are either smaller or similar to the IV model. Adding regional dummies tends to reduce the indirect effects by about one third. But estimates from other specifications, based on recent changes, IV and occupational unemployment rates, tend to generate higher estimates. The baseline estimates thus present a reasonable median case. The estimates for the direct effects, on the other hand, are relatively invariant to model specifications when expressed in proportion to the effect of income on well-being.

To evaluate the direct costs on the unemployed themselves, we first estimate the reduction in income associated with unemployment by regressing the log of household income on personal unemployment status, together with all the covariates in Tables 1 that include gender, age, education, race and others. In the BRFSS data, personal unemployment status has a coefficient of -0.36 in the income equation, indicating a $43 \%$ income difference between the unemployed and others with similar characteristics. In the Gallup-Healthways survey, the estimated difference is 0.34 in logs or $40 \%$. These estimate are likely higher-end estimates of the income losses from unemployment, as there could be unobserved factors responsible for a lower level of income as well as a higher 
chance of being unemployed. This potential bias strengthens our later argument that monetary loss is a small part of the costs of unemployment. How does the lower income affect well-being? The log income's per-unit effects on well-being are reported in Tables 1 . For life satisfaction, the effect is 0.2 . A 0.36 reduction in log income has a negative impact of $0.36^{*} 0.2=0.072$. The well-being equation in Tables 1 also shows the coefficient on personal unemployment status. Those coefficients measure the nonpecuniary effect of personal unemployment, since the income variable is already controlled for. For life satisfaction, personal unemployment's coefficient is -0.4. The ratio of nonpecuniary to pecuniary effects from personal unemployment is thus $0.4 / 0.072=5.6 .^{10}$

There is an extra pecuniary effect on other household members of the newly unemployed. A job loss reduces household income, and hence negatively affects all members of the household according to our model specification. The average household size is 2.58 according to the 2010 Census Briefs. So there is a 1.58 times additional monetary effects on SWB through the within-household spillover effects.

To evaluate the indirect cost at the population level, we use the estimated coefficients on local unemployment in Tables 1 . In the life satisfaction equation, local unemployment has a coefficient of -0.59 . The indirect cost of a one percentage point increase in unemployment is thus $0.59^{*} 1$ percent. Since the US labor force participation rate is about 65 percent, a 1 percent increase in the unemployment rate moves 0.65 percent of the population from the employment pool to the unemployment pool. The direct well-being loss due to monetary

\footnotetext{
${ }^{10}$ Our approach does not distinguish between temporary and permanent effects of income changes from unemployment. Knabe and Ratzel (2011) suggest that not making such distinction leads to overestimating the nonpecuniary costs of unemployment by about one-third. But because the nonpecuniary costs in our data are on average several times as big as the monetary costs, adjusting the estimates downward by one third would not change the picture substantially.
} 
losses, as calculated before, is 0.072 individually and thus $0.072 * 0.65$ at the aggregate. The direct nonpecuniary effect is 0.4 individually and $0.4^{*} 0.65$ at the aggregate. The ratio of the indirect loss to the direct pecuniary and nonpecuniary loss is therefore $\frac{0.59}{0.072 * 0.65+0.4 * 0.65}=1.9$. Alternatively, we can express the indirect effect as a multiple of the direct pecuniary effects on the unemployed. In this case, the indirect effect is $\frac{0.59}{0.072 * 0.65}=12.6$ as big.

Table 3 lists the decomposition for all the measures of well-being. Its last two columns show the ratio of indirect effects to direct effects, and the ratio of total non-pecuniary effects to pecuniary effects. They show that the nonmonetary cost of unemployment is about 6 to 9 times as large as the monetary costs, and that the indirect effects of unemployment at the population level are substantially greater than the direct loss suffered by the unemployed themselves. Individually the indirect effects are small, but they affect a much broader population.

Table 3: Comparing the direct and indirect costs of unemployment - with direct cost to the unemployed workers due to monetary losses normalized to 1

\begin{tabular}{|c|c|c|c|c|c|c|}
\hline & \multicolumn{2}{|c|}{ Direct costs } & \multicolumn{2}{|c|}{ Indirect costs } & \multicolumn{2}{|c|}{ Ratios } \\
\hline & $\begin{array}{c}\text { monetary } \\
\text { loss }\end{array}$ & $\begin{array}{c}\text { nonmonetary } \\
\text { loss }\end{array}$ & $\begin{array}{l}\text { monetary: } \\
\text { same } \\
\text {-household }\end{array}$ & $\begin{array}{c}\text { nonmonetary: } \\
\text { population } \\
\text {-wide }\end{array}$ & $\begin{array}{l}\text { indirect } \\
\text { to direct }\end{array}$ & $\begin{array}{l}\text { non-monetary } \\
\text { to monetary }\end{array}$ \\
\hline Life satisfaction & 1 & 5.6 & 1.58 & 12.6 & 2.1 & 7.1 \\
\hline Days of bad mental health & 1 & 7.3 & 1.58 & 11.6 & 1.6 & 7.3 \\
\hline Life ladder & 1 & 4.2 & 1.58 & 19 & 4.0 & 9.0 \\
\hline Pseudo $\mathrm{u}$-index & 1 & 3.3 & 1.58 & 15.2 & 3.9 & 7.2 \\
\hline Positive emotions & 1 & 2.2 & 1.58 & 16.2 & 5.6 & 7.1 \\
\hline Negative emotions & 1 & 3.9 & 1.58 & 12.5 & 2.9 & 6.4 \\
\hline
\end{tabular}

We can summarize the accounting exercise using the averages from the first four measures of well-being: if the direct monetary loss of the unemployed themselves is 1 , the additional SWB loss of the unemployed is about 5, while 
at the population level the indirect or spillover effect is about 16 including the impact of monetary loss to other household members. All together, the total well-being costs of unemployment are about 20 times as large as those directly due to the lower incomes of the unemployed.

\section{Conclusion}

This paper estimates the impact of aggregate unemployment on subjective wellbeing, using two recent large-scale American surveys, the Gallup-Healthways Well-Being Index from 2008 to 2011 and the Centers for Disease Control and Prevention's Behavioral Risk Factor Surveillance System (BRFSS) in recent years and since the early 1990s in some cases. We contribute to a literature that is relatively thin in US-based evidence with larger samples, finer-grained contextual information and alternative model specifications.

We find robust evidence that unemployment has significant indirect effects on the population, particularly so for those who are still employed. The basic specification correlates individual well-being with unemployment statistics at the county level. But the evidence holds up well in a variety of models, including those that use alternative sources of variation based on external industrial trends and occupational unemployment rates. We find weaker estimates of the indirect effect from the fixed-effects model and higher estimates from instrumental variables based on external industrial trends that are strong predictors of unemployment losses in the near future. We interpret the latter result as indicating that the anticipation of future employment losses has negative effects on subjective well-being. We also explore the channel behind the indirect

effect, and find evidence indicative of the importance of job security, including substantial negative effects of workplace downsizing on the well-being of still- 
employed workers. Overall we find stronger, more clear-cut evidence from the Gallup-Healthways surveys than from the BRFSS. The former provides consistent evidence both cross-sectionally and over time. The BRFSS shows strong cross-sectional relationships, but much weaker relationships over time.

In the aggregate, the spillover effects are substantially greater than the direct well-being costs for the unemployed themselves. For those who are still employed, a one percentage point increase in local unemployment has an effect on subjective well-being close to that of a four percent fall in household income. The income equivalents are calculated based on the estimated cross-sectional relationship between household income and subjective well-being, which potentially suffer biases of uncertain directions. The estimated income equivalents serve only as a crude indication that the spillover effects of unemployment are economically meaningful. 


\section{References}

Blanchflower, D. G. (2007, October). Is unemployment more costly than inflation? NBER Working Papers 13505, National Bureau of Economic Research, Inc.

Chadi, A. (2013). Regional unemployment and norm-induced effects on life satisfaction. Empirical Economics, 1-31.

Clark, A., A. Knabe, and S. Rtzel (2010). Boon or bane? others' unemployment, well-being and job insecurity. Labour Economics 17(1), 52 - 61 .

Clark, A. E. (2003, April). Unemployment as a social norm: Psychological evidence from panel data. Journal of Labor Economics 21(2), 289-322.

Deaton, A. (2012, January). The financial crisis and the well-being of Americans. Oxford Economic Papers 64(1), 1-26.

Di Tella, R., R. J. MacCulloch, and A. J. Oswald (2001, March). Preferences over inflation and unemployment: Evidence from surveys of happiness. American Economic Review $91(1), 335-341$.

Di Tella, R., R. J. MacCulloch, and A. J. Oswald (2003, 09). The macroeconomics of happiness. The Review of Economics and Statistics 85 (4), 809-827.

Easterlin, R. A. (1974). Does economic growth improve the human lot? In P. A. David and M. W. Reder (Eds.), Nations and Households in Economic Growth: Essays in Honor of Moses Abramovitz, Volume 4. New York: Academic Press, Inc. 
Ferrer-i-Carbonell, A. and P. Frijters $(2004,07)$. How important is methodology for the estimates of the determinants of happiness? Economic Journal 114(497), 641-659.

Helliwell, J. F. and H. Huang (2009). How's the job? well-being and social capital in the workplace. Industrial and Labor Relations Review 63(2, article 2).

Kahneman, D. and A. Deaton (2010, September). High income improves evaluation of life but not emotional well-being. PNAS 107(38), 16489-16493.

Kahneman, D. and A. B. Krueger (2006, Winter). Developments in the measurement of subjective well-being. Journal of Economic Perspectives 20(1), $3-24$.

Kassenboehmer, S. C. and J. P. Haisken-DeNew (2009, 03). You're fired! the causal negative effect of entry unemployment on life satisfaction. Economic Journal 119(536), 448-462.

Knabe, A. and S. Ratzel (2011). Quantifying the psychological costs of unemployment: the role of permanent income. Applied Economics 43(21), $2751-2763$.

Lazarus, R. S. (1966). Psychological Stress and the Coping Process. McGrawHill.

Lazarus, R. S. and S. Folkman (1984). Stress, Appraisal, and Coping. Springer Pub. Co.

Luechinger, S., S. Meier, and A. Stutzer (2010). Why does unemployment hurt 
the employed?: Evidence from the life satisfaction gap between the public and the private sector. J. Human Resources 45(4), 998-1045.

Mavridis, D. (2010, May). Can subjective well-being predict unemployment length? Policy Research Working Paper Series 5293, The World Bank.

Oswald, A. and S. Wu (2010). Objective confirmation of subjective measures of human well-being: Evidence from the usa. Science (327), 576-78.

Powdthavee, N. (2007). Are there geographical variations in the psychological cost of unemployment in South Africa? Social Indicators Research 80(3), pp. 629-652.

Raphael, S. and R. Winter-Ember (2001, April). Identifying the effect of unemployment on crime. Journal of Law and Economics 44(1), 259-83.

Shields, M., S. W. Price, and M. Wooden (2009, April). Life satisfaction and the economic and social characteristics of neighbourhoods. Journal of Population Economics 22(2), 421-443.

Shields, M. A. and S. W. Price (2005). Exploring the economic and social determinants of psychological well-being and perceived social support in England. Journal of the Royal Statistical Society Series A 168(3), 513-537.

Winkelmann, L. and R. Winkelmann (1998, February). Why are the unemployed so unhappy? evidence from panel data. Economica 65(257), 1-15.

Wolfers, J. (2003, Spring). Is business cycle volatility costly? evidence from surveys of subjective well-being. International Finance 6(1), 1-26. 


\section{A Appendix}

Table A.1: Data sources

\begin{tabular}{ll}
\hline \multicolumn{1}{c}{ Data } & Source \\
\hline BRFSS & Center for Disease Control and Prevention \\
& www.cdc.gov/BRFSS \\
Gallup-Healthways Well-Being Index & The Gallup Organization \\
& Data version: As of April 2012 \\
& Availability: please contact the Gallup Organization \\
County and state-level unemployment & BLS Local Area Unemployment Statistics program \\
& www.bls.gov/lau/ \\
County-level census (2000) profile & Missouri Census Data Center sf32000x/ Standard \\
& Extract; http://mcdc.missouri.edu/census2000/ \\
IV for county unemployment rates & Quarterly Census of Employment and Wage program \\
\hline
\end{tabular}


Figure A.1: Measures of well-being from the BRFSS; 2005-10 for life satisfaction; 1994-2010 for mental health; un-weighted histograms
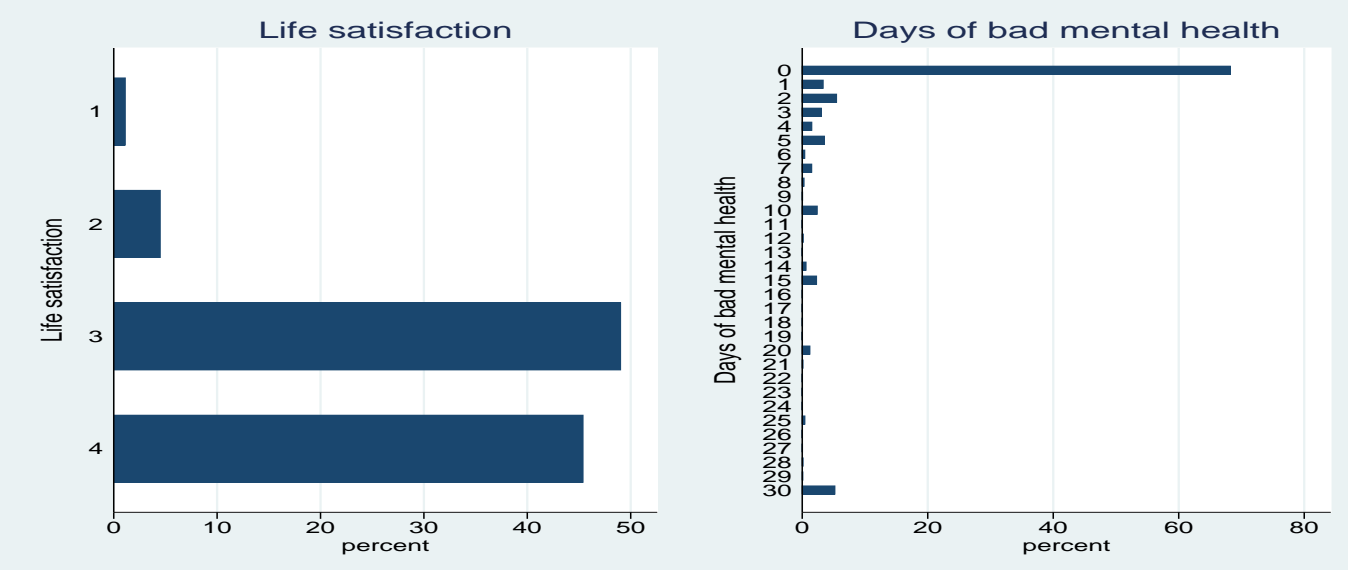

Source: BRFSS; 2005-2010 for life satisfaction; 1994-2010 for mental health

Figure A.2: Measures of well-being from the Gallup-Healthways Well-Being Index, 2008-2011; un-weighted histograms
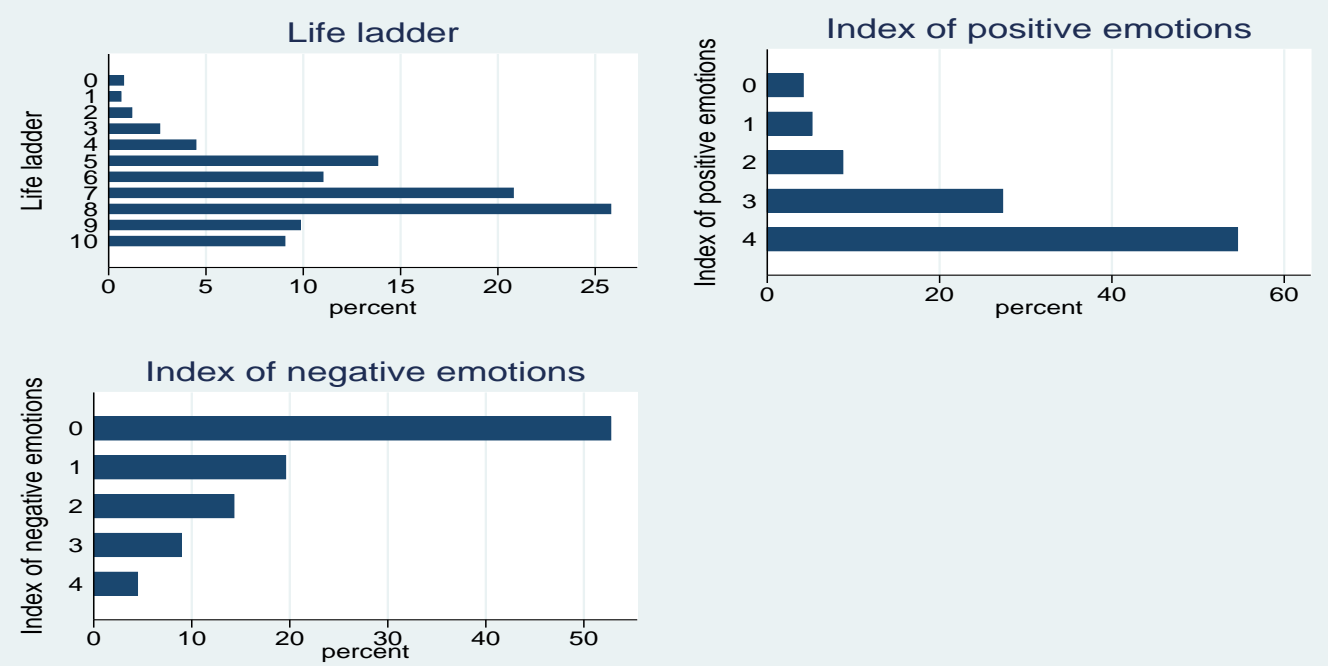

Source: Gallup-Healthways 2008-2011. Unweighted histogram 
Table A.2: Distribution of household income in the 2005-10 BRFSS

\begin{tabular}{lrr}
\hline Annual income & Number & Per cent \\
\hline Less than $\$ 10,000$ & 111,234 & 5 \\
Between $\$ 10,000$ and $\$ 15,000$ & 108,867 & 5 \\
Between $\$ 15,000$ and $\$ 20,000$ & 151,352 & 6 \\
Between $\$ 20,000$ and $\$ 25,000$ & 184,801 & 8 \\
Between $\$ 25,000$ and $\$ 35,000$ & 240,016 & 10 \\
Between $\$ 35,000$ and $\$ 50,000$ & 312,409 & 13 \\
Between $\$ 50,000$ and $\$ 75,000$ & 352,036 & 15 \\
Greater than $\$ 75,000$ & 639,401 & 27 \\
Information is missing & 300,348 & 13 \\
Total & $2,400,465$ & 100 \\
\hline
\end{tabular}

Table A.3: Distribution of annual household income in the 1994-2010 BRFSS

\begin{tabular}{lrr}
\hline Annual income & Number & Per cent \\
\hline Less than $\$ 10,000$ & 245,952 & 6 \\
Between $\$ 10,000$ and $\$ 15,000$ & 223,773 & 5 \\
Between $\$ 15,000$ and $\$ 20,000$ & 305,897 & 7 \\
Between $\$ 20,000$ and $\$ 25,000$ & 375,990 & 9 \\
Between $\$ 25,000$ and $\$ 35,000$ & 538,120 & 12 \\
Between $\$ 35,000$ and $\$ 50,000$ & 648,281 & 15 \\
Between $\$ 50,000$ and $\$ 75,000$ & 629,504 & 14 \\
Greater than $\$ 75,000$ & 832,591 & 19 \\
Information is missing & 577,919 & 13 \\
Total & $4,378,028$ & 100 \\
\hline
\end{tabular}


Table A.4: Distribution of household income in the Gallup-Healthways survey 2008-2011

\begin{tabular}{lrr}
\hline Monthly income & Number & Per cent \\
\hline$\$ 500$ to $\$ 900$ & 62,250 & 4 \\
$\$ 1,000$ to $\$ 1,999$ & 150,004 & 11 \\
$\$ 2,000$ to $\$ 2,999$ & 148,594 & 11 \\
$\$ 3,000$ to $\$ 3,999$ & 131,578 & 9 \\
$\$ 4,000$ to $\$ 4,999$ & 115,707 & 8 \\
$\$ 5,000$ to $\$ 7,499$ & 195,621 & 14 \\
$\$ 7,500$ to $\$ 9,999$ & 85,006 & 6 \\
$\$ 10,000$ and above & 160,563 & 12 \\
Information is missing & 336,573 & 24 \\
Total & $1,385,896$ & 100 \\
\hline
\end{tabular}

Table A.5: Summary statistics for other variables in the 1994-2010 BRFSS

\begin{tabular}{lccccc}
\hline \hline \multicolumn{1}{c}{ Variable } & Mean & Std. Dev. & Min. & Max. & N \\
\hline Male & 0.48 & 0.5 & 0 & 1 & 4378028 \\
Age 18 to 29 & 0.21 & 0.41 & 0 & 1 & 4378028 \\
Age 30 to 49 & 0.38 & 0.49 & 0 & 1 & 4378028 \\
Age 50 to 64 & 0.21 & 0.41 & 0 & 1 & 4378028 \\
Age 65 or above & 0.17 & 0.38 & 0 & 1 & 4378028 \\
Edu: High sch. or below & 0.43 & 0.5 & 0 & 1 & 4378028 \\
Edu: Some post-secondary & 0.27 & 0.44 & 0 & 1 & 4378028 \\
Edu: University degree & 0.3 & 0.46 & 0 & 1 & 4378028 \\
Single/never married & 0.19 & 0.39 & 0 & 1 & 4378028 \\
Married/with partner & 0.63 & 0.48 & 0 & 1 & 4378028 \\
Divorced/seprt./widowed & 0.18 & 0.39 & 0 & 1 & 4378028 \\
Race: White & 0.72 & 0.45 & 0 & 1 & 4346870 \\
Race: Black & 0.1 & 0.29 & 0 & 1 & 4346870 \\
Race: Hispanic & 0.13 & 0.34 & 0 & 1 & 4346870 \\
Race: Others & 0.06 & 0.23 & 0 & 1 & 4346870 \\
LFS: Work for pay & 0.53 & 0.5 & 0 & 1 & 4378028 \\
LFS: Unemployed & 0.05 & 0.22 & 0 & 1 & 4378028 \\
LFS: Self-employed & 0.08 & 0.28 & 0 & 1 & 4378028 \\
LFS: Retired & 0.16 & 0.37 & 0 & 1 & 4378028 \\
LFS: Student & 0.04 & 0.21 & 0 & 1 & 4378028 \\
LFS: Home maker & 0.08 & 0.27 & 0 & 1 & 4378028 \\
LFS: Disability & 0.04 & 0.2 & 0 & 1 & 4378028 \\
UR: unemployment in county & 0.06 & 0.03 & 0.01 & 0.39 & 3497276 \\
URST: unemployment in state & 0.06 & 0.02 & 0.02 & 0.15 & 4293870 \\
\hline
\end{tabular}


Table A.6: Summary statistics for other variables in the 2008-2011 Gallup-Healthways Poll

\begin{tabular}{lccccc}
\hline \hline \multicolumn{1}{c}{ Variable } & Mean & Std. Dev. & Min. & Max. & N \\
\hline Pseudo u-index & 0.11 & 0.31 & 0 & 1 & 1359474 \\
Male & 0.48 & 0.5 & 0 & 1 & 1385895 \\
Age 18 to 29 & 0.18 & 0.38 & 0 & 1 & 1362218 \\
Age 30 to 49 & 0.34 & 0.47 & 0 & 1 & 1362218 \\
Age 50 to 64 & 0.26 & 0.44 & 0 & 1 & 1362218 \\
Age 65 or above & 0.2 & 0.4 & 0 & 1 & 1385896 \\
Edu: High sch. or below & 0.47 & 0.5 & 0 & 1 & 1366699 \\
Edu: Some post-secondary & 0.22 & 0.42 & 0 & 1 & 1366699 \\
Edu: University degree & 0.31 & 0.46 & 0 & 1 & 1366699 \\
Single/never married & 0.21 & 0.41 & 0 & 1 & 1368445 \\
Married/with partner & 0.6 & 0.49 & 0 & 1 & 1368445 \\
Divorced/seprt./widowed & 0.19 & 0.4 & 0 & 1 & 1368445 \\
Race*: White & 0.74 & 0.44 & 0 & 1 & 1104267 \\
Race*: Black & 0.1 & 0.3 & 0 & 1 & 1104267 \\
Race*: Hispanic & 0.11 & 0.32 & 0 & 1 & 1104267 \\
Race*: Others & 0.05 & 0.22 & 0 & 1 & 1104267 \\
LFS: Work for pay & 0.54 & 0.5 & 0 & 1 & 1385896 \\
LFS: Unemployed & 0.04 & 0.21 & 0 & 1 & 1374256 \\
LFS: Not in labour force & 0.36 & 0.48 & 0 & 1 & 1356948 \\
Unemployment at county level & 0.08 & 0.03 & 0.01 & 0.32 & 1369736 \\
Unemployment at state level & 0.08 & 0.02 & 0.03 & 0.15 & 1385896 \\
\hline
\end{tabular}

* The race/ethnicity information shown here are from data between 2008q1 to 2011q2. Since 2011q2, the Gallup-Healthways has a different treatment of racial classification that allows many more possible combinations of multiple races. We create a separate set of dummy indicators and include them in the regression analysis. 
Table A.7: Alternative model specifications - full samples

\begin{tabular}{|c|c|c|c|c|c|c|}
\hline Variables & $\begin{array}{c}\begin{array}{c}\text { Life } \\
\text { satisfaction }\end{array} \\
(1)\end{array}$ & $\begin{array}{c}\begin{array}{c}\text { Days of bad } \\
\text { mental health }\end{array} \\
(2)\end{array}$ & $\begin{array}{c}\begin{array}{c}\text { Life } \\
\text { ladder }\end{array} \\
(3) \\
\end{array}$ & $\begin{array}{c}\begin{array}{l}\text { Pseudo } \\
\text { u-index }\end{array} \\
(4)\end{array}$ & $\begin{array}{c}\begin{array}{c}\text { Positive } \\
\text { emotions }\end{array} \\
(5)\end{array}$ & $\begin{array}{c}\begin{array}{c}\text { Negative } \\
\text { emotions }\end{array} \\
(6)\end{array}$ \\
\hline \multicolumn{7}{|l|}{ Use both county \& state UR } \\
\hline Log of household income & $\begin{array}{c}0.2 \\
(0.008)^{* * *}\end{array}$ & $\begin{array}{c}-.90 \\
(0.03)^{* * *}\end{array}$ & $\begin{array}{c}0.24 \\
(0.004)^{* * *}\end{array}$ & $\begin{array}{c}-.27 \\
(0.004)^{* * *}\end{array}$ & $\begin{array}{c}0.17 \\
(0.003)^{* * *}\end{array}$ & $\begin{array}{c}-.22 \\
(0.003)^{* * *}\end{array}$ \\
\hline Unemployment (fraction) in county & $\begin{array}{c}-.42 \\
(0.16)^{* * *}\end{array}$ & $\begin{array}{l}1.72 \\
(1.06)\end{array}$ & $\begin{array}{c}-.73 \\
(0.14)^{* * *}\end{array}$ & $\begin{array}{c}0.87 \\
(0.16)^{* * *}\end{array}$ & $\begin{array}{c}-.69 \\
(0.12)^{* * * *}\end{array}$ & $\begin{array}{c}0.55 \\
(0.11)^{* * *}\end{array}$ \\
\hline Unemployment (fraction) in state & $\begin{array}{l}-.32 \\
(0.25)\end{array}$ & $\begin{array}{l}1.74 \\
(1.28)\end{array}$ & $\begin{array}{c}-.53 \\
(0.19)^{* * *}\end{array}$ & $\begin{array}{l}0.08 \\
(0.26)\end{array}$ & $\begin{array}{l}0.15 \\
(0.18)\end{array}$ & $\begin{array}{l}0.11 \\
(0.17)\end{array}$ \\
\hline $\begin{array}{l}\text { Obs. } \\
R^{2}\end{array}$ & 1939405 & $\begin{array}{c}3310113 \\
0.08\end{array}$ & 1283025 & 1267079 & 1270822 & 1284254 \\
\hline$F$ statistic & 491.92 & 416.94 & 709.67 & 335.74 & 338.85 & 604.69 \\
\hline \multicolumn{7}{|l|}{ Use lag and changes in unemployment } \\
\hline Log of household income & $\begin{array}{c}0.2 \\
(0.008)^{* * *}\end{array}$ & $\begin{array}{c}-.90 \\
(0.03)^{* * *}\end{array}$ & $\begin{array}{c}0.24 \\
(0.004)^{* * *}\end{array}$ & $\begin{array}{c}-.27 \\
(0.004)^{* * *}\end{array}$ & $\begin{array}{c}0.17 \\
(0.003)^{* * *}\end{array}$ & $\begin{array}{c}-.22 \\
(0.003)^{* * *}\end{array}$ \\
\hline$\Delta$ unemployment from same qtr. last year & $\begin{array}{l}-.23 \\
(0.21)\end{array}$ & $\begin{array}{c}3.48 \\
(1.22)^{* * *}\end{array}$ & $\begin{array}{l}-1.41 \\
(0.15)^{* * *}\end{array}$ & $\begin{array}{c}1.18 \\
(0.22)^{* * *}\end{array}$ & $\begin{array}{c}-.58 \\
(0.14)^{* * *}\end{array}$ & $\begin{array}{c}0.93 \\
(0.15)^{* * *}\end{array}$ \\
\hline Unemployment same quarter last year & $\begin{array}{c}-.71 \\
(0.14)^{* * *}\end{array}$ & $\begin{array}{c}2.30 \\
(0.85)^{* * *}\end{array}$ & $\begin{array}{l}-.92 \\
(0.1)^{* * *}\end{array}$ & $\begin{array}{c}0.86 \\
(0.12)^{* * *}\end{array}$ & $\begin{array}{c}-.62 \\
(0.09)^{* * *}\end{array}$ & $\begin{array}{c}0.54 \\
(0.08)^{* * *}\end{array}$ \\
\hline $\begin{array}{l}\text { Obs. } \\
R^{2}\end{array}$ & 1938463 & $\begin{array}{c}3309159 \\
0.08\end{array}$ & 1283025 & 1267079 & 1270822 & 1284254 \\
\hline$F$ statistic & 492.42 & 418.97 & 703.2 & 335.69 & 339.18 & 603.5 \\
\hline \multicolumn{7}{|l|}{ County Fixed-effect model } \\
\hline Log of household income & $\begin{array}{c}0.11 \\
(0.005)^{* * *}\end{array}$ & $\begin{array}{c}-.91 \\
(0.04)^{* * *}\end{array}$ & $\begin{array}{c}0.5 \\
(0.008)^{* * *}\end{array}$ & $\begin{array}{c}-.06 \\
(0.0009)^{* * *}\end{array}$ & $\begin{array}{c}0.18 \\
(0.003)^{* * *}\end{array}$ & $\begin{array}{c}-.25 \\
(0.003)^{* * *}\end{array}$ \\
\hline Unemployment (fraction) in county & $\begin{array}{l}0.19 \\
(0.13)\end{array}$ & $\begin{array}{l}-.35 \\
(0.91)\end{array}$ & $\begin{array}{l}-1.15 \\
(0.28)^{* * *}\end{array}$ & $\begin{array}{l}0.07 \\
(0.05)\end{array}$ & $\begin{array}{l}-.28 \\
(0.16)^{*}\end{array}$ & $\begin{array}{l}0.06 \\
(0.17)\end{array}$ \\
\hline Obs. & 1939405 & 3310113 & 1283025 & 1267079 & 1270822 & 1284254 \\
\hline$R^{2}$ & 0.11 & 0.08 & 0.09 & 0.05 & 0.05 & 0.07 \\
\hline$F$ statistic & 613.95 & 430.49 & 977.72 & 348.37 & 362.46 & 871.78 \\
\hline \multicolumn{7}{|l|}{ Adding Regional Dummies } \\
\hline Log of household income & $\begin{array}{c}0.11 \\
(0.005)^{* * *}\end{array}$ & $\begin{array}{c}-.90 \\
(0.04)^{* * *}\end{array}$ & $\begin{array}{c}0.5 \\
(0.008)^{* * *}\end{array}$ & $\begin{array}{c}-.06 \\
(0.0009)^{* * *}\end{array}$ & $\begin{array}{c}0.18 \\
(0.003)^{* * *}\end{array}$ & $\begin{array}{c}-.25 \\
(0.003)^{* * *}\end{array}$ \\
\hline Unemployment fraction at county level & $\begin{array}{c}-.18 \\
(0.06)^{* * *}\end{array}$ & $\begin{array}{c}2.21 \\
(0.89)^{* *}\end{array}$ & $\begin{array}{l}-1.58 \\
(0.18)^{* * *}\end{array}$ & $\begin{array}{c}0.13 \\
(0.02)^{* * *}\end{array}$ & $\begin{array}{c}-.51 \\
(0.08)^{* * *}\end{array}$ & $\begin{array}{c}0.52 \\
(0.08)^{* * *}\end{array}$ \\
\hline Obs. & 1939405 & 3310113 & 1283025 & 1267079 & 1270822 & 1284254 \\
\hline$R^{2}$ & 0.11 & 0.08 & 0.09 & 0.04 & 0.04 & 0.06 \\
\hline$F$ statistic & 528.72 & 426.16 & & 291.12 & 319.37 & . \\
\hline \multicolumn{7}{|l|}{ Instrumental-variable model } \\
\hline Log of household income & $\begin{array}{c}0.11 \\
(0.005)^{* * *}\end{array}$ & $\begin{array}{c}-.90 \\
(0.04)^{* * *}\end{array}$ & $\begin{array}{c}0.51 \\
(0.008)^{* * *}\end{array}$ & $\begin{array}{c}-.06 \\
(0.001)^{* * *}\end{array}$ & $\begin{array}{c}0.18 \\
(0.004)^{* * *}\end{array}$ & $\begin{array}{c}-.26 \\
(0.004)^{* * *}\end{array}$ \\
\hline Unemployment (fraction) in county & $\begin{array}{c}-.51 \\
(0.13)^{* * *}\end{array}$ & $\begin{array}{c}4.14 \\
(1.71)^{* *}\end{array}$ & $\begin{array}{l}-4.01 \\
(0.43)^{* * *}\end{array}$ & $\begin{array}{c}0.2 \\
(0.05)^{* * *}\end{array}$ & $\begin{array}{c}-.40 \\
(0.19)^{* *}\end{array}$ & $\begin{array}{c}0.76 \\
(0.22)^{* * *}\end{array}$ \\
\hline Obs. & 1939405 & 3310113 & 960081 & 948043 & 950890 & 961270 \\
\hline$R^{2}$ & 0.11 & 0.08 & 0.09 & 0.04 & 0.04 & 0.06 \\
\hline$F$ statistic & 570.59 & 444.06 & 1009.34 & 321.94 & 346.33 & 784.9 \\
\hline
\end{tabular}

Notes: (1) All regressions include the right-hand-side variables that are present in the regressions in Table 1. (2) The fixed-effects model, the IV model and the model with regional dummies use linear estimations, making their individual coefficients not comparable to those from other panels. Switching between linear and probit models affects the estimated coefficients roughly proportionally. As a result, the ratio of coefficients shown in Table 2 are on a comparable scale.

Appendix - page 6 
Table A.8: Alternative model specifications - samples of employed workers

\begin{tabular}{|c|c|c|c|c|c|c|}
\hline Variables & $\begin{array}{c}\begin{array}{c}\text { Life } \\
\text { satisfaction }\end{array} \\
(1)\end{array}$ & $\begin{array}{c}\begin{array}{c}\text { Days of bad } \\
\text { mental health }\end{array} \\
(2)\end{array}$ & $\begin{array}{c}\begin{array}{c}\text { Life } \\
\text { ladder }\end{array} \\
(3)\end{array}$ & $\begin{array}{l}\begin{array}{c}\text { Pseudo } \\
\text { u-index }\end{array} \\
(4)\end{array}$ & $\begin{array}{c}\begin{array}{c}\text { Positive } \\
\text { emotions }\end{array} \\
(5)\end{array}$ & $\begin{array}{c}\begin{array}{l}\text { Negative } \\
\text { emotions }\end{array} \\
(6)\end{array}$ \\
\hline \multicolumn{7}{|l|}{ Use both county \& state UR } \\
\hline Log of household income & $\begin{array}{c}0.22 \\
(0.01)^{* * *}\end{array}$ & $\begin{array}{c}-.74 \\
(0.04)^{* * *}\end{array}$ & $\begin{array}{c}0.25 \\
(0.005)^{* * *}\end{array}$ & $\begin{array}{c}-.20 \\
(0.006)^{* * *}\end{array}$ & $\begin{array}{c}0.1 \\
(0.004)^{* * *}\end{array}$ & $\begin{array}{c}-.16 \\
(0.004)^{* * *}\end{array}$ \\
\hline Unemployment (fraction) in county & $\begin{array}{l}-.14 \\
(0.24)\end{array}$ & $\begin{array}{l}1.60 \\
(1.12)\end{array}$ & $\begin{array}{l}-.70 \\
(0.18)^{* * *}\end{array}$ & $\begin{array}{l}1.10 \\
(0.22)^{* * *}\end{array}$ & $\begin{array}{l}-.77 \\
(0.16)^{* * *}\end{array}$ & $\begin{array}{c}0.4 \\
(0.16)^{* *}\end{array}$ \\
\hline Unemployment (fraction) in state & $\begin{array}{c}-.82 \\
(0.32)^{* * *}\end{array}$ & $\begin{array}{l}2.26 \\
(1.43)\end{array}$ & $\begin{array}{c}-.67 \\
(0.24)^{* * * *}\end{array}$ & $\begin{array}{l}-.34 \\
(0.31)\end{array}$ & $\begin{array}{c}0.2 \\
(0.21)\end{array}$ & $\begin{array}{l}0.33 \\
(0.22)\end{array}$ \\
\hline $\begin{array}{l}\text { Obs. } \\
R^{2}\end{array}$ & 863833 & $\begin{array}{c}1604097 \\
0.03\end{array}$ & 640286 & 634859 & 636078 & 640257 \\
\hline$F$ statistic & 288.3 & 202.35 & 408.31 & 111.43 & 114.75 & 212.79 \\
\hline $\begin{array}{l}\text { Use lag and changes in UR } \\
\text { Log of household income }\end{array}$ & $\begin{array}{c}0.22 \\
(0.01)^{* * *}\end{array}$ & $\begin{array}{c}-.74 \\
(0.04)^{* * *}\end{array}$ & $\begin{array}{c}0.25 \\
(0.005)^{* * *}\end{array}$ & $\begin{array}{c}-.20 \\
(0.006)^{* * *}\end{array}$ & $\begin{array}{c}0.1 \\
(0.004)^{* * *}\end{array}$ & $\begin{array}{c}-.16 \\
(0.004)^{* * *}\end{array}$ \\
\hline$\Delta$ unemployment from same qtr. last year & $\begin{array}{r}-.34 \\
(0.3)\end{array}$ & $\begin{array}{l}3.04 \\
(1.51)^{* *}\end{array}$ & $\begin{array}{l}-1.45 \\
(0.2)^{* * *}\end{array}$ & $\frac{1.31}{(0.33)^{* * *}}$ & $\begin{array}{l}-.71 \\
(0.2)^{* * *}\end{array}$ & $\begin{array}{l}0.97 \\
(0.21)^{* * *}\end{array}$ \\
\hline Unemployment same quarter last year & $\begin{array}{l}-.69 \\
(0.22)^{* * *}\end{array}$ & $\underset{(0.97)^{* * *}}{2.51}$ & $\begin{array}{c}-.99 \\
(0.12)^{* * *}\end{array}$ & $\begin{array}{c}0.83 \\
(0.16)^{* * *}\end{array}$ & $\begin{array}{l}-.65 \\
(0.11)^{* * *}\end{array}$ & $\begin{array}{l}0.5 \\
(0.11)^{* * *}\end{array}$ \\
\hline $\begin{array}{l}\text { Obs. } \\
R^{2}\end{array}$ & 863363 & $\begin{array}{c}1603624 \\
0.03\end{array}$ & 640286 & 634859 & 636078 & 640257 \\
\hline$F$ statistic & 289.65 & 203.15 & 406.54 & 111.11 & 115.1 & 214.32 \\
\hline $\begin{array}{l}\text { County Fixed-effect model } \\
\text { Log of household income }\end{array}$ & $\begin{array}{c}0.12 \\
(0.006)^{* * *}\end{array}$ & $\begin{array}{c}-.75 \\
(0.05)^{* * *}\end{array}$ & $\begin{array}{c}0.46 \\
(0.009)^{* * *}\end{array}$ & $\begin{array}{c}-.04 \\
(0.001)^{* * *}\end{array}$ & $\begin{array}{c}0.11 \\
(0.004)^{* * *}\end{array}$ & $\begin{array}{c}-.18 \\
(0.004)^{* * *}\end{array}$ \\
\hline Unemployment (fraction) by occupation & $\begin{array}{l}0.21 \\
(0.16)\end{array}$ & $\begin{array}{c}0.3 \\
(1.02)\end{array}$ & $\begin{array}{l}-1.11 \\
(0.4)^{* * *}\end{array}$ & $\begin{array}{l}0.12 \\
(0.05)^{* *}\end{array}$ & $\begin{array}{c}-.39 \\
(0.19)^{* *}\end{array}$ & $\begin{array}{l}0.14 \\
(0.22)\end{array}$ \\
\hline $\begin{array}{l}\text { Obs. } \\
R^{2} \\
F \text { statistic }\end{array}$ & $\begin{array}{c}863833 \\
0.08 \\
360.86\end{array}$ & $\begin{array}{c}1604097 \\
0.03 \\
210.04\end{array}$ & $\begin{array}{c}640286 \\
0.09 \\
557.53\end{array}$ & $\begin{array}{c}634859 \\
0.02 \\
127.98\end{array}$ & $\begin{array}{c}636078 \\
0.03 \\
128.58\end{array}$ & $\begin{array}{c}640257 \\
0.04 \\
266.24\end{array}$ \\
\hline \multicolumn{7}{|l|}{ Adding Regional Dummies } \\
\hline Log of household income & $\begin{array}{c}0.12 \\
(0.006)^{* * *}\end{array}$ & $\begin{array}{l}-.74 \\
(0.04)^{* * *}\end{array}$ & $\begin{array}{c}0.46 \\
(0.009)^{* * *}\end{array}$ & $\begin{array}{l}-.03 \\
(0.001)^{* * *}\end{array}$ & $\begin{array}{l}0.1 \\
(0.004)^{* * *}\end{array}$ & $\begin{array}{l}-.18 \\
(0.004)^{* * *}\end{array}$ \\
\hline Unemployment fraction at county level & $\begin{array}{l}-.14 \\
(0.09)\end{array}$ & $\begin{array}{l}2.07 \\
(1.04)^{* *}\end{array}$ & $\begin{array}{l}-1.44 \\
(0.2)^{* * *}\end{array}$ & $\begin{array}{c}0.1 \\
(0.02)^{* * *}\end{array}$ & $\begin{array}{l}-.46 \\
(0.1)^{* * *}\end{array}$ & $\begin{array}{l}0.42 \\
(0.11)^{* * *}\end{array}$ \\
\hline Obs. & 863833 & 1604097 & 640286 & 634859 & 636078 & 640257 \\
\hline$R^{2}$ & 0.07 & 0.03 & 0.08 & 0.01 & 0.02 & 0.03 \\
\hline$F$ statistic & 309.37 & 211.04 & 481.05 & . & 105.82 & . \\
\hline \multicolumn{7}{|l|}{ Instrumental-variable model } \\
\hline Log of household income & $\begin{array}{c}0.12 \\
(0.006)^{* * *}\end{array}$ & $\begin{array}{c}-.74 \\
(0.04)^{* * * *}\end{array}$ & $\begin{array}{c}0.47 \\
(0.01)^{* * *}\end{array}$ & $\begin{array}{c}-.03 \\
(0.001)^{* * *}\end{array}$ & $\begin{array}{c}0.1 \\
(0.005)^{* * *}\end{array}$ & $\begin{array}{c}-.19 \\
(0.005)^{* * *}\end{array}$ \\
\hline Unemployment (fraction) in county & $\begin{array}{l}-.56 \\
(0.19)^{* * *}\end{array}$ & $\begin{array}{l}3.22 \\
(1.97)\end{array}$ & $\begin{array}{l}-3.88 \\
(0.47)^{* * *}\end{array}$ & $\begin{array}{c}0.23 \\
(0.05)^{* * *}\end{array}$ & $\begin{array}{l}-.58 \\
(0.21)^{* * *}\end{array}$ & $\frac{0.91}{(0.24)^{* * *}}$ \\
\hline Obs. & 863833 & 1604097 & 468468 & 464438 & 465335 & 468510 \\
\hline$R^{2}$ & 0.07 & 0.03 & 0.08 & 0.01 & 0.02 & 0.03 \\
\hline$F$ statistic & 332.53 & 214.8 & 615.75 & 110.74 & 125.71 & 275.68 \\
\hline \multicolumn{7}{|l|}{ Use occupation-specific unemployment } \\
\hline Log of household income & & & $\begin{array}{c}0.24 \\
(0.006)^{* * *}\end{array}$ & $\begin{array}{c}-.19 \\
(0.007)^{* * *}\end{array}$ & $\begin{array}{c}0.1 \\
(0.005)^{* * *}\end{array}$ & $\begin{array}{c}-.17 \\
(0.005)^{* * *}\end{array}$ \\
\hline Unemployment (fraction) in county & & & $\begin{array}{l}-1.10 \\
(0.13)^{* * *}\end{array}$ & $\begin{array}{c}0.99 \\
(0.17)^{* * *}\end{array}$ & $\begin{array}{c}-.71 \\
(0.12)^{* * *}\end{array}$ & $\begin{array}{c}0.63 \\
(0.11)^{* * *}\end{array}$ \\
\hline Unemployment (fraction) by occupation & & & $\begin{array}{c}-1.17 \\
(0.06)^{* * *}\end{array}$ & $\begin{array}{c}0.79 \\
(0.1)^{* * *}\end{array}$ & $\begin{array}{l}-1.07 \\
(0.07)^{* * *}\end{array}$ & $\begin{array}{l}-.17 \\
(0.07)^{* *}\end{array}$ \\
\hline Obs. & & & 475829 & 471942 & 472800 & 475843 \\
\hline$F$ statistic & & & 336.26 & 81.25 & 96.57 & 163.75 \\
\hline
\end{tabular}

Notes: (1) All regressions include the right-hand-side variables that are present in the regressions in Table 1. (2) The fixed-effect model, the IV model and the model with regional dummies use linear estimatiph malking their individual coefficients not comparable to those from other panels. Switching between linear and probit models affects the estimated coefficients roughly proportionally. As a result, the ratios of coefficients shown in Table 2 are on a comparable scale. 
Table A.9: Estimates from the full samples- Linear regressions with state dummy indicators

\begin{tabular}{|c|c|c|c|c|c|c|}
\hline & $\begin{array}{c}\text { Life } \\
\text { satisfaction } \\
(1)\end{array}$ & $\begin{array}{c}\begin{array}{c}\text { Days of bad } \\
\text { mental health }\end{array} \\
(2)\end{array}$ & $\begin{array}{c}\begin{array}{c}\text { Life } \\
\text { ladder }\end{array} \\
(3)\end{array}$ & $\begin{array}{l}\begin{array}{c}\text { Pseudo } \\
\text { u-index }\end{array} \\
(4)\end{array}$ & $\begin{array}{c}\begin{array}{c}\text { Positive } \\
\text { emotions }\end{array} \\
(5)\end{array}$ & $\begin{array}{c}\begin{array}{c}\text { Negative } \\
\text { emotions }\end{array} \\
(6)\end{array}$ \\
\hline Log of household income & $\begin{array}{c}0.11 \\
(0.005)^{* * *}\end{array}$ & $\begin{array}{c}-.90 \\
(0.04)^{* * *}\end{array}$ & $\begin{array}{c}0.5 \\
(0.008)^{* * *}\end{array}$ & $\begin{array}{c}-.06 \\
(0.0009)^{* * *}\end{array}$ & $\begin{array}{c}0.18 \\
(0.003)^{* * *}\end{array}$ & $\begin{array}{c}-.25 \\
(0.003)^{* * *}\end{array}$ \\
\hline LFS: Unemployed & $\begin{array}{l}-.22 \\
(0.005)^{* * *}\end{array}$ & $\begin{array}{l}2.38 \\
(0.06)^{* * *}\end{array}$ & $\begin{array}{l}-.70 \\
(0.01)^{* * *}\end{array}$ & $\begin{array}{c}0.06 \\
(0.002)^{* * *}\end{array}$ & $\begin{array}{l}-.14 \\
(0.007)^{* * *}\end{array}$ & $\begin{array}{c}0.35 \\
(0.008)^{* * *}\end{array}$ \\
\hline Unemployment fraction at county level & $\begin{array}{l}-.01 \\
(0.08)\end{array}$ & $\begin{array}{l}0.57 \\
(0.75)\end{array}$ & $\begin{array}{l}-.98 \\
(0.22)^{* * *}\end{array}$ & $\begin{array}{c}0.1 \\
(0.03)^{* * *}\end{array}$ & $\begin{array}{l}-.44 \\
(0.09)^{* * *}\end{array}$ & $\begin{array}{c}0.38 \\
(0.11)^{* * *}\end{array}$ \\
\hline Male & $\begin{array}{l}-.02 \\
(0.002)^{* * *}\end{array}$ & $\begin{array}{l}-.96 \\
(0.02)^{* * *}\end{array}$ & $\begin{array}{l}-.30 \\
(0.005)^{* * *}\end{array}$ & $\begin{array}{c}-.008 \\
(0.0007)^{* * *}\end{array}$ & $\begin{array}{c}-.06 \\
(0.003)^{* * *}\end{array}$ & $\begin{array}{l}-.12 \\
(0.003)^{* * *}\end{array}$ \\
\hline Age 18 to 29 & $\begin{array}{c}0.06 \\
(0.004)^{* * *}\end{array}$ & $\begin{array}{c}0.2 \\
(0.03)^{* * *}\end{array}$ & $\begin{array}{c}0.37 \\
(0.009)^{* * *}\end{array}$ & $\begin{array}{l}-.05 \\
(0.001)^{* * *}\end{array}$ & $\begin{array}{c}0.23 \\
(0.005)^{* * *}\end{array}$ & $\begin{array}{l}-.09 \\
(0.005)^{* * *}\end{array}$ \\
\hline Age 50 to 64 & $\begin{array}{c}0.03 \\
(0.003)^{* * *}\end{array}$ & $\begin{array}{l}-.72 \\
(0.03)^{* * *}\end{array}$ & $\begin{array}{c}0.03 \\
(0.007)^{* * *}\end{array}$ & $\begin{array}{l}-.007 \\
(0.001)^{* * *}\end{array}$ & $\begin{array}{l}0.001 \\
(0.004)\end{array}$ & $\begin{array}{l}-.16 \\
(0.004)^{* * *}\end{array}$ \\
\hline Age 65 or above & $\begin{array}{c}0.12 \\
(0.003)^{* * *}\end{array}$ & $\begin{array}{l}-2.19 \\
(0.04)^{* * *}\end{array}$ & $\begin{array}{c}0.64 \\
(0.008)^{* * *}\end{array}$ & $\begin{array}{l}-.10 \\
(0.002)^{* * *}\end{array}$ & $\begin{array}{c}0.24 \\
(0.006)^{* * *}\end{array}$ & $\begin{array}{l}-.69 \\
(0.006)^{* * *}\end{array}$ \\
\hline Edu: High sch. or below & $\begin{array}{l}-.02 \\
(0.003)^{* * *}\end{array}$ & $\begin{array}{l}0.01 \\
(0.02)\end{array}$ & $\begin{array}{l}-.05 \\
(0.007)^{* * *}\end{array}$ & $\begin{array}{l}0.01 \\
(0.001)^{* * *}\end{array}$ & $\begin{array}{l}-.12 \\
(0.004)^{* * *}\end{array}$ & $\begin{array}{l}-.01 \\
(0.004)^{* * *}\end{array}$ \\
\hline Edu: University degree & $\begin{array}{c}0.07 \\
(0.002)^{* * *}\end{array}$ & $\begin{array}{l}-.62 \\
(0.02)^{* * *}\end{array}$ & $\begin{array}{c}0.3 \\
(0.006)^{* * *}\end{array}$ & $\begin{array}{c}-.01 \\
(0.0008)^{* * *}\end{array}$ & $\begin{array}{c}0.07 \\
(0.003)^{* * *}\end{array}$ & $\begin{array}{c}-.03 \\
(0.004)^{* * *}\end{array}$ \\
\hline Married/with partner & $\begin{array}{c}0.15 \\
(0.004)^{* * *}\end{array}$ & $\begin{array}{c}-.26 \\
(0.03)^{* * *}\end{array}$ & $\begin{array}{c}0.15 \\
(0.008)^{* * *}\end{array}$ & $\begin{array}{c}-.01 \\
(0.001)^{* * *}\end{array}$ & $\begin{array}{c}0.08 \\
(0.004)^{* * *}\end{array}$ & $\begin{array}{c}0.0001 \\
(0.005)\end{array}$ \\
\hline Divorced/seprt./widowed & $\begin{array}{l}-.02 \\
(0.004)^{* * *}\end{array}$ & $\begin{array}{c}0.7 \\
(0.04)^{* * *}\end{array}$ & $\begin{array}{c}-.23 \\
(0.009)^{* * *}\end{array}$ & $\begin{array}{c}0.03 \\
(0.001)^{* * *}\end{array}$ & $\begin{array}{l}-.08 \\
(0.005)^{* * *}\end{array}$ & $\begin{array}{c}0.14 \\
(0.005)^{* * *}\end{array}$ \\
\hline Race: Black & $\begin{array}{l}-.002 \\
(0.004)\end{array}$ & $\begin{array}{l}-.58 \\
(0.04)^{* * *}\end{array}$ & $\begin{array}{c}0.16 \\
(0.01)^{* * *}\end{array}$ & $\begin{array}{l}-.02 \\
(0.002)^{* * *}\end{array}$ & $\begin{array}{c}0.04 \\
(0.007)^{* * *}\end{array}$ & $\begin{array}{l}-.21 \\
(0.008)^{* * *}\end{array}$ \\
\hline Race: Hispanic & $\begin{array}{c}0.03 \\
(0.005)^{* * *}\end{array}$ & $\begin{array}{l}-.72 \\
(0.04)^{* * *}\end{array}$ & $\begin{array}{c}0.2 \\
(0.01)^{* * *}\end{array}$ & $\begin{array}{l}-.003 \\
(0.002)^{*}\end{array}$ & $\begin{array}{c}0.05 \\
(0.006)^{* * *}\end{array}$ & $\begin{array}{l}-.01 \\
(0.008)^{*}\end{array}$ \\
\hline Race: Others & $\begin{array}{c}-.05 \\
(0.007)^{* * *}\end{array}$ & $\begin{array}{c}-.15 \\
(0.05)^{* * *}\end{array}$ & $\begin{array}{l}-.14 \\
(0.01)^{* * *}\end{array}$ & $\begin{array}{c}0.01 \\
(0.002)^{* * *}\end{array}$ & $\begin{array}{c}-.04 \\
(0.008)^{* * *}\end{array}$ & $\begin{array}{c}0.04 \\
(0.009)^{* * *}\end{array}$ \\
\hline Log(avg. income in cnty) & $\begin{array}{l}-.007 \\
(0.008)\end{array}$ & $\begin{array}{l}-.17 \\
(0.1)^{*}\end{array}$ & $\begin{array}{c}0.06 \\
(0.03)^{* *}\end{array}$ & $\begin{array}{c}-.01 \\
(0.003)^{* * *}\end{array}$ & $\begin{array}{c}0.04 \\
(0.01)^{* * *}\end{array}$ & $\begin{array}{l}0.02 \\
(0.01)\end{array}$ \\
\hline Log(pop./sq. mile in cnty) & $\begin{array}{c}-.01 \\
(0.002)^{* * *}\end{array}$ & $\begin{array}{c}0.09 \\
(0.02)^{* * *}\end{array}$ & $\begin{array}{c}-.04 \\
(0.005)^{* * *}\end{array}$ & $\begin{array}{c}0.006 \\
(0.0007)^{* * *}\end{array}$ & $\begin{array}{c}-.02 \\
(0.002)^{* * *}\end{array}$ & $\begin{array}{c}0.03 \\
(0.003)^{* * *}\end{array}$ \\
\hline \multicolumn{7}{|l|}{ Other variables: see footnotes } \\
\hline $\begin{array}{l}\text { Obs. } \\
R^{2} \\
\end{array}$ & $\begin{array}{c}1939405 \\
0.11 \\
\end{array}$ & $\begin{array}{c}3310113 \\
0.08 \\
\end{array}$ & $\begin{array}{c}1283025 \\
0.09 \\
\end{array}$ & $\begin{array}{c}1267079 \\
0.04 \\
\end{array}$ & $\begin{array}{c}1270822 \\
0.04 \\
\end{array}$ & $\begin{array}{c}1284254 \\
0.06 \\
\end{array}$ \\
\hline
\end{tabular}

Notes: (1) Standard errors in parentheses. ${ }^{*}, * *$, and $* * *$ indicate statistical significance at 10 percent, 5 percent and 1 percent levels. (2) Other variables include a set of year-quarter dummies, the indicator of top income bracket, the indicator for missing income information, county-level average household income, population density, share of urban population, of owner-occupied housing, of black residents, of Hispanic residents, and of other minorities, the longitude and latitude of county centres, and indicators for Alaska and Hawaii. (3) All regressions use survey linear regression due to the inclusion of a large number of state dummy indicators. The estimated coefficients are thus not directly comparable to those based on ordered probit models. All use survey weights and cluster errors by county. 
Table A.10: Estimates from the samples of employed workers - Linear regressions with state dummy indicators

\begin{tabular}{|c|c|c|c|c|c|c|}
\hline & $\begin{array}{c}\begin{array}{c}\text { Life } \\
\text { satisfaction }\end{array} \\
(1)\end{array}$ & $\begin{array}{c}\begin{array}{c}\text { Days of bad } \\
\text { mental health }\end{array} \\
(2)\end{array}$ & $\begin{array}{c}\begin{array}{c}\text { Life } \\
\text { ladder }\end{array} \\
(3)\end{array}$ & $\begin{array}{c}\begin{array}{l}\text { Pseudo } \\
\text { u-index }\end{array} \\
(4)\end{array}$ & $\begin{array}{c}\begin{array}{c}\text { Positive } \\
\text { emotions }\end{array} \\
(5)\end{array}$ & $\begin{array}{c}\begin{array}{l}\text { Negative } \\
\text { emotions }\end{array} \\
(6)\end{array}$ \\
\hline Log of household income & $\begin{array}{c}0.12 \\
(0.006)^{* * *}\end{array}$ & $\begin{array}{c}-.74 \\
(0.05)^{* * *}\end{array}$ & $\begin{array}{c}0.46 \\
(0.009)^{* * *}\end{array}$ & $\begin{array}{c}-.03 \\
(0.001)^{* * *}\end{array}$ & $\begin{array}{c}0.1 \\
(0.004)^{* * *}\end{array}$ & $\begin{array}{c}-.18 \\
(0.004)^{* * *}\end{array}$ \\
\hline Unemployment fraction at county level & $\begin{array}{l}0.11 \\
(0.11)\end{array}$ & $\begin{array}{l}0.33 \\
(0.76)\end{array}$ & $\begin{array}{c}-.87 \\
(0.27)^{* * *}\end{array}$ & $\begin{array}{c}0.11 \\
(0.03)^{* * *}\end{array}$ & $\begin{array}{c}-.46 \\
(0.12)^{* * *}\end{array}$ & $\begin{array}{c}0.31 \\
(0.14)^{* *}\end{array}$ \\
\hline Male & $\begin{array}{c}-.02 \\
(0.003)^{* * *}\end{array}$ & $\begin{array}{l}-1.18 \\
(0.02)^{* * * *}\end{array}$ & $\begin{array}{c}-.21 \\
(0.005)^{* * *}\end{array}$ & $\begin{array}{c}-.02 \\
(0.001)^{* * *}\end{array}$ & $\begin{array}{c}-.02 \\
(0.004)^{* * *}\end{array}$ & $\begin{array}{c}-.14 \\
(0.004)^{* * *}\end{array}$ \\
\hline Age 18 to 29 & $\begin{array}{c}0.05 \\
(0.005)^{* * *}\end{array}$ & $\begin{array}{c}0.45 \\
(0.03)^{* * *}\end{array}$ & $\begin{array}{c}0.29 \\
(0.01)^{* * *}\end{array}$ & $\begin{array}{c}-.03 \\
(0.001)^{* * *}\end{array}$ & $\begin{array}{c}0.16 \\
(0.006)^{* * *}\end{array}$ & $\begin{array}{c}-.02 \\
(0.006)^{* * *}\end{array}$ \\
\hline Age 50 to 64 & $\begin{array}{c}0.02 \\
(0.002)^{* * *}\end{array}$ & $\begin{array}{c}-.66 \\
(0.02)^{* * *}\end{array}$ & $\begin{array}{c}0.03 \\
(0.007)^{* * *}\end{array}$ & $\begin{array}{c}-.01 \\
(0.001)^{* * *}\end{array}$ & $\begin{array}{c}0.02 \\
(0.004)^{* * *}\end{array}$ & $\begin{array}{c}-.14 \\
(0.004)^{* * *}\end{array}$ \\
\hline Age 65 or above & $\begin{array}{c}0.14 \\
(0.005)^{* * *}\end{array}$ & $\begin{array}{l}-2.00 \\
(0.04)^{* * *}\end{array}$ & $\begin{array}{c}0.51 \\
(0.01)^{* * *}\end{array}$ & $\begin{array}{c}-.06 \\
(0.002)^{* * *}\end{array}$ & $\begin{array}{c}0.19 \\
(0.006)^{* * *}\end{array}$ & $\begin{array}{c}-.49 \\
(0.007)^{* * *}\end{array}$ \\
\hline Edu: High sch. or below & $\begin{array}{c}-.02 \\
(0.004)^{* * *}\end{array}$ & $\begin{array}{c}0.08 \\
(0.03)^{* * * *}\end{array}$ & $\begin{array}{c}-.07 \\
(0.008)^{* * *}\end{array}$ & $\begin{array}{c}0.007 \\
(0.001)^{* * *}\end{array}$ & $\begin{array}{c}-.08 \\
(0.005)^{* * *}\end{array}$ & $\begin{array}{c}-.04 \\
(0.005)^{* * *}\end{array}$ \\
\hline Edu: University degree & $\begin{array}{c}0.07 \\
(0.003)^{* * *}\end{array}$ & $\begin{array}{c}-.63 \\
(0.02)^{* * *}\end{array}$ & $\begin{array}{c}0.3 \\
(0.007)^{* * *}\end{array}$ & $\begin{array}{c}-.01 \\
(0.001)^{* * *}\end{array}$ & $\begin{array}{c}0.08 \\
(0.004)^{* * *}\end{array}$ & $\begin{array}{c}-.02 \\
(0.005)^{* * *}\end{array}$ \\
\hline Married/with partner & $\begin{array}{c}0.16 \\
(0.005)^{* * *}\end{array}$ & $\begin{array}{c}-.34 \\
(0.03)^{* * * *}\end{array}$ & $\begin{array}{c}0.14 \\
(0.009)^{* * *}\end{array}$ & $\begin{array}{l}-.007 \\
(0.001)^{* * *}\end{array}$ & $\begin{array}{c}0.06 \\
(0.005)^{* * *}\end{array}$ & $\begin{array}{l}0.001 \\
(0.005)\end{array}$ \\
\hline Divorced/seprt./widowed & $\begin{array}{c}-.02 \\
(0.005)^{* * *}\end{array}$ & $\begin{array}{c}0.81 \\
(0.04)^{* * *}\end{array}$ & $\begin{array}{c}-.28 \\
(0.01)^{* * *}\end{array}$ & $\begin{array}{c}0.03 \\
(0.002)^{* * *}\end{array}$ & $\begin{array}{c}-.06 \\
(0.007)^{* * *}\end{array}$ & $\begin{array}{c}0.16 \\
(0.007)^{* * *}\end{array}$ \\
\hline Race: Black & $\begin{array}{c}-.03 \\
(0.006)^{* * *}\end{array}$ & $\begin{array}{c}-.46 \\
(0.04)^{* * *}\end{array}$ & $\begin{array}{c}0.04 \\
(0.01)^{* * *}\end{array}$ & $\begin{array}{l}-.008 \\
(0.002)^{* * *}\end{array}$ & $\begin{array}{c}0.01 \\
(0.007)^{*}\end{array}$ & $\begin{array}{c}-.20 \\
(0.009)^{* * *}\end{array}$ \\
\hline Race: Hispanic & $\begin{array}{c}0.04 \\
(0.006)^{* * *}\end{array}$ & $\begin{array}{c}-.61 \\
(0.04)^{* * *}\end{array}$ & $\begin{array}{c}0.16 \\
(0.01)^{* * *}\end{array}$ & $\begin{array}{l}-.002 \\
(0.002)\end{array}$ & $\begin{array}{c}0.04 \\
(0.007)^{* * *}\end{array}$ & $\begin{array}{c}-.02 \\
(0.009)\end{array}$ \\
\hline Race: Others & $\begin{array}{c}-.06 \\
(0.008)^{* * *}\end{array}$ & $\begin{array}{c}-.14 \\
(0.05)^{* *}\end{array}$ & $\begin{array}{c}-.13 \\
(0.02)^{* * *}\end{array}$ & $\begin{array}{c}0.01 \\
(0.002)^{* * *}\end{array}$ & $\begin{array}{c}-.04 \\
(0.009)^{* * *}\end{array}$ & $\begin{array}{c}0.005 \\
(0.01)\end{array}$ \\
\hline Log(avg. income in cnty) & $\begin{array}{l}-.01 \\
(0.01)\end{array}$ & $\begin{array}{c}-.19 \\
(0.09)^{* *}\end{array}$ & $\begin{array}{c}0.005 \\
(0.03)\end{array}$ & $\begin{array}{l}0.007 \\
(0.004)^{*}\end{array}$ & $\begin{array}{l}-.02 \\
(0.01)\end{array}$ & $\begin{array}{c}0.09 \\
(0.01)^{* * *}\end{array}$ \\
\hline Log(pop./sq. mile in cnty) & $\begin{array}{c}-.008 \\
(0.002)^{* * *}\end{array}$ & $\begin{array}{c}0.08 \\
(0.02)^{* * * *}\end{array}$ & $\begin{array}{c}-.03 \\
(0.006)^{* * *}\end{array}$ & $\begin{array}{c}0.004 \\
(0.0007)^{* * * *}\end{array}$ & $\begin{array}{c}-.01 \\
(0.003)^{* * *}\end{array}$ & $\begin{array}{c}0.02 \\
(0.003)^{* * *}\end{array}$ \\
\hline \multicolumn{7}{|l|}{ Other variables: see footnotes } \\
\hline $\begin{array}{l}\text { Obs. } \\
R^{2}\end{array}$ & $\begin{array}{c}863833 \\
0.07\end{array}$ & $\begin{array}{c}1604097 \\
0.03\end{array}$ & $\begin{array}{c}640286 \\
0.08\end{array}$ & $\begin{array}{c}634859 \\
0.01\end{array}$ & $\begin{array}{c}636078 \\
0.02\end{array}$ & $\begin{array}{c}640257 \\
0.03\end{array}$ \\
\hline
\end{tabular}

Notes: (1) Standard errors in parentheses. $*, * *$, and $* * *$ indicate statistical significance at 10 percent, 5 percent and 1 percent levels. (2) Other variables include a set of year-quarter dummies, the indicator of top income bracket, the indicator for missing income information, county-level average household income, population density, share of urban population, of owner-occupied housing, of black residents, of Hispanic residents, and of other minorities, the longitude and latitude of county centres, and indicators for Alaska and Hawaii. (3) All regressions use survey linear regression due to the inclusion of a large number of state dummy indicators. The estimated coefficients are thus not directly comparable to those based on ordered probit models. All use survey weights and cluster errors by county. 
Table A.11: Workplace expansion and downsizing - samples of employed workers

\begin{tabular}{|c|c|c|c|c|}
\hline & $\begin{array}{c}\begin{array}{c}\text { Life } \\
\text { ladder }\end{array} \\
(1)\end{array}$ & $\begin{array}{l}\begin{array}{l}\text { Pseudo } \\
\text { u-index }\end{array} \\
(2)\end{array}$ & $\begin{array}{c}\begin{array}{c}\text { Positive } \\
\text { emotions }\end{array} \\
(3)\end{array}$ & $\begin{array}{c}\begin{array}{c}\text { Negative } \\
\text { emotions }\end{array} \\
(4)\end{array}$ \\
\hline Log of household income & $\begin{array}{c}0.24 \\
(0.006)^{* * *}\end{array}$ & $\begin{array}{c}-.20 \\
(0.008)^{* * *}\end{array}$ & $\begin{array}{c}0.1 \\
(0.005)^{* * *}\end{array}$ & $\begin{array}{c}-.17 \\
(0.005)^{* * *}\end{array}$ \\
\hline Unemployment fraction at county level & $\begin{array}{c}-.85 \\
(0.12)^{* * *}\end{array}$ & $\begin{array}{c}0.59 \\
(0.16)^{* * *}\end{array}$ & $\begin{array}{l}-.43 \\
(0.11)^{* * *}\end{array}$ & $\begin{array}{c}0.29 \\
(0.11)^{* *}\end{array}$ \\
\hline Workplace expanding & $\begin{array}{c}0.11 \\
(0.004)^{* * *}\end{array}$ & $\begin{array}{c}-.11 \\
(0.009)^{* * *}\end{array}$ & $\begin{array}{c}0.14 \\
(0.005)^{* * *}\end{array}$ & $\begin{array}{c}-.05 \\
(0.005)^{* * *}\end{array}$ \\
\hline Workplace downsizing & $\begin{array}{c}-.19 \\
(0.005)^{* * *}\end{array}$ & $\begin{array}{c}0.31 \\
(0.009)^{* * *}\end{array}$ & $\begin{array}{c}-.16 \\
(0.006)^{* * *}\end{array}$ & $\begin{array}{c}0.3 \\
(0.006)^{* * *}\end{array}$ \\
\hline Male & $\begin{array}{c}-.14 \\
(0.004)^{* * *}\end{array}$ & $\begin{array}{c}-.11 \\
(0.007)^{* * *}\end{array}$ & $\begin{array}{c}-.04 \\
(0.005)^{* * *}\end{array}$ & $\begin{array}{c}-.14 \\
(0.004)^{* * *}\end{array}$ \\
\hline Age 18 to 29 & $\begin{array}{c}0.15 \\
(0.007)^{* * *}\end{array}$ & $\begin{array}{c}-.14 \\
(0.01)^{* * *}\end{array}$ & $\begin{array}{c}0.17 \\
(0.007)^{* * *}\end{array}$ & $\begin{array}{c}0.01 \\
(0.007)^{*}\end{array}$ \\
\hline Age 50 to 64 & $\begin{array}{c}0.03 \\
(0.005)^{* * *}\end{array}$ & $\begin{array}{c}-.06 \\
(0.008)^{* * *}\end{array}$ & $\begin{array}{c}0.03 \\
(0.005)^{* * *}\end{array}$ & $\begin{array}{c}-.15 \\
(0.005)^{* * *}\end{array}$ \\
\hline Age 65 or above & $\begin{array}{c}0.3 \\
(0.009)^{* * *}\end{array}$ & $\begin{array}{c}-.42 \\
(0.02)^{* * *}\end{array}$ & $\begin{array}{c}0.21 \\
(0.009)^{* * *}\end{array}$ & $\begin{array}{c}-.51 \\
(0.01)^{* * *}\end{array}$ \\
\hline Edu: High sch. or below & $\begin{array}{c}-.01 \\
(0.005)^{* * *}\end{array}$ & $\begin{array}{c}0.04 \\
(0.01)^{* * *}\end{array}$ & $\begin{array}{c}-.10 \\
(0.006)^{* * *}\end{array}$ & $\begin{array}{c}-.05 \\
(0.006)^{* * *}\end{array}$ \\
\hline Edu: University degree & $\begin{array}{c}0.18 \\
(0.005)^{* * *}\end{array}$ & $\begin{array}{c}-.12 \\
(0.009)^{* * *}\end{array}$ & $\begin{array}{c}0.11 \\
(0.006)^{* * *}\end{array}$ & $\begin{array}{c}-.02 \\
(0.005)^{* * *}\end{array}$ \\
\hline Married/with partner & $\begin{array}{c}0.11 \\
(0.006)^{* * *}\end{array}$ & $\begin{array}{c}-.06 \\
(0.01)^{* * *}\end{array}$ & $\begin{array}{c}0.06 \\
(0.007)^{* * *}\end{array}$ & $\begin{array}{l}-.01 \\
(0.006)\end{array}$ \\
\hline Divorced/seprt./widowed & $\begin{array}{c}-.14 \\
(0.008)^{* * *}\end{array}$ & $\begin{array}{c}0.13 \\
(0.01)^{* * *}\end{array}$ & $\begin{array}{c}-.05 \\
(0.009)^{* * *}\end{array}$ & $\begin{array}{c}0.14 \\
(0.008)^{* * *}\end{array}$ \\
\hline Race: Black & $\begin{array}{c}0.03 \\
(0.009)^{* * *}\end{array}$ & $\begin{array}{c}-.04 \\
(0.02)^{* *}\end{array}$ & $\begin{array}{l}-.01 \\
(0.01)\end{array}$ & $\begin{array}{c}-.21 \\
(0.01)^{* * *}\end{array}$ \\
\hline Race: Hispanic & $\begin{array}{c}0.13 \\
(0.01)^{* * *}\end{array}$ & $\begin{array}{l}-.01 \\
(0.02)\end{array}$ & $\begin{array}{c}0.03 \\
(0.009)^{* * *}\end{array}$ & $\begin{array}{c}-.04 \\
(0.01)^{* * *}\end{array}$ \\
\hline Race: Others & $\begin{array}{c}-.06 \\
(0.01)^{* * *}\end{array}$ & $\begin{array}{c}0.07 \\
(0.02)^{* * *}\end{array}$ & $\begin{array}{c}-.04 \\
(0.01)^{* * *}\end{array}$ & $\begin{array}{c}-.004 \\
(0.01)\end{array}$ \\
\hline Log(avg. income in cnty) & $\begin{array}{c}-.04 \\
(0.02)^{* *}\end{array}$ & $\begin{array}{c}0.07 \\
(0.02)^{* * *}\end{array}$ & $\begin{array}{l}-.02 \\
(0.02)\end{array}$ & $\begin{array}{c}0.09 \\
(0.01)^{* * *}\end{array}$ \\
\hline Log(pop./sq. mile in cnty) & $\begin{array}{c}-.01 \\
(0.003)^{* * *}\end{array}$ & $\begin{array}{c}0.02 \\
(0.005)^{* * *}\end{array}$ & $\begin{array}{c}-.02 \\
(0.003)^{* * *}\end{array}$ & $\begin{array}{c}0.02 \\
(0.003)^{* * *}\end{array}$ \\
\hline \multicolumn{5}{|l|}{ Other variables: see footnote 4} \\
\hline $\begin{array}{l}\text { Obs. } \\
R^{2}\end{array}$ & 459040 & 455450 & 456268 & 458940 \\
\hline$F$ statistic & 330.97 & 116.97 & 135.22 & 215.22 \\
\hline
\end{tabular}

Notes: (1) Standard errors in parentheses. ${ }^{*}, * *$, and $* * *$ indicate statistical significance at 10 percent, 5 percent and 1 percent levels. (2) Other variables include a set of year-quarter dummies, the indicator of top income bracket, the indicator for missing income information, county-level average household income, population density, share of urban population, of owner-occupied housing, of black residents, of Hispanic residents, and of other minorities, the longitude and latitude of county centres, and indicators for Alaska and Hawaii. (3) All regressions use survey ordered probit models. All use survey weights and cluster errors by county. 